\title{
Systematic investigation of imprinted gene expression and enrichment in the mouse brain explored at single-cell resolution
}

\author{
M. J. Higgs ${ }^{1}$, M. J. Hill²,3, R. M. John ${ }^{4}$, and A. R. Isles ${ }^{1, *}$
}

1 Behavioural Genetics Group, MRC Centre for Neuropsychiatric, Genetics and Genomics, Neuroscience and Mental Health Research Institute, Cardiff University, Cardiff, UK

2 Division of Psychological Medicine and Clinical Neurosciences, MRC Centre for Neuropsychiatric Genetics and Genomics, School of Medicine, Cardiff University, Cardiff, UK

3 UK Dementia Research Institute, School of Medicine, Cardiff University, Cardiff, UK

4 School of Biosciences, Cardiff University, Cardiff, UK

* Corresponding author: A. R. Isles, Behavioural Genetics Group, MRC Centre for Neuropsychiatric Genetics and Genomics, Neuroscience and Mental Health Research Institute, Cardiff University, Cardiff CF24 4HQ, UK. E-mail: islesar1@ cardiff.ac.uk

\section{Abstract}

Although a number of imprinted genes are known to be highly expressed in the brain, and in certain brain regions in particular, whether they are truly over-represented in the brain has never been formally tested. Using fifteen single-cell RNA sequencing datasets we take a systematic approach to investigate imprinted gene over-representation at the organ, brain region, and cellspecific levels. We establish that imprinted genes are indeed over-represented in the adult brain, and in neurons particularly compared to other brain cell-types. We then examine brain-wide datasets to examine enrichment within distinct regions of the brain and demonstrate overrepresentation of imprinted genes in the hypothalamus, ventral midbrain, pons and medulla. Finally, using datasets focusing on these regions of enrichment, we were able to identify hypothalamic neuroendocrine populations and the monoaminergic hindbrain neurons as specific hotspots of imprinted gene expression. These analyses provide the first robust assessment of the neural systems on which imprinted genes converge. Moreover, the unbiased approach, with each analysis informed by the findings of the previous level, permits highly informed inferences about the functions on which imprinted genes converge. Our findings indicate the neuronal regulation of motivated behaviours such as feeding, parental behaviour and sleep as functional hotspots for imprinting, thus adding statistically rigour to prior assumptions and providing testable predictions for novel neural and behavioural phenotypes 
associated with specific genes and imprinted gene networks. In turn, this work sheds further light on the potential evolutionary drivers of genomic imprinting in the brain.

\section{Introduction}

Imprinted genes demonstrate a preferential or exclusively monoallelic expression from either the maternal or paternal allele in an epigenetically predetermined manner (a parent-of-origin effect, POE), and to date approximately 200 canonical (associated with a parental specific epigenetic mark) imprinted genes have been identified in the mouse ( 150 in humans) (Ferguson-Smith 2011; Tucci et al. 2019). This epigenetic regulation makes genomic imprinting an evolutionary puzzle as these genes are effectively haploid and thereby negate many of the benefits of diploidy (Orr 1995). Studying the patterns of expression and function of imprinted genes may therefore shed light on the drivers leading to the evolution of genomic imprinting. For instance, functional characterization of a number of imprinted genes points to convergence on placental function (Peters 2014), in line with the predictions of early theoretical ideas (Moore and Haig 1991). Outside of the placenta, the brain consistently emerges as an adult tissue with a large number of expressed imprinted genes (Gregg et al. 2010; Babak et al. 2015; Andergassen et al. 2017). However, given that it is estimated that $\sim 80 \%$ of all genes in the genome are expressed in the brain (Lein et al. 2007; Negi and Guda 2017), the question remains, is imprinted gene expression actually enriched in the brain compared to other adult tissues? To date this has never been formally tested.

A role for imprinted genes in the brain was suggested by (Cattanach and Kirk 1985) and neurological phenotypes (Keverne et al. 1996a) observed in early imprinted gene mouse models, as well as the behavioural deficits seen in imprinting disorders such as Prader-Willi 
several imprinted genes are involved in the processes of neural differentiation, migration, axonal outgrowth and apoptosis (Perez et al. 2016). In the adult brain, studies of mice carrying manipulations of individual imprinted genes have suggested a wide range of behavioural roles including maternal care (Li et al. 1999), feeding (Davies et al. 2015), social behaviour (Garfield et al. 2011; McNamara et al. 2018), learning and memory (Jiang et al. 1998), cognition (Relkovic et al. 2010; Dent et al. 2018), and more recently, sleep and circadian activity (Lassi et al. 2012).

In addition to studies on individual imprinted genes, there are a limited number of studies that take a systems level approach to characterizing the role of genomic imprinting in the brain. The early studies examining developing and adult chimeras of normal and parthenogenetic (two paternal genomes) or androgenetic/gynogenetic (two maternal genomes) cells indicated distinct regional distribution for maternal (cortex and hippocampus) and paternal (hypothalamus) expressed genes (Allen et al. 1995; Keverne et al. 1996a). More recently, Gregg et al. (2010) used the known imprinting status of 45 imprinted genes and the Allen Brain Atlas to track dichotomous expression of imprinted genes across 118 brain regions to identify brain-wide patterns of expression. Most imprinted genes were expressed in every brain region, but detectable expression of the largest number of imprinted genes was found in regions of the hypothalamus (MPOA, ARC), amygdala (CEA, MEA) and the monoaminergic nuclei, suggesting some form of specialisation. Although pioneering, this study, and others identifying novel imprinted genes and/or mapping allelic expression in the brain (DeVeale et al. 2012; Babak et al. 2015; Perez et al. 2015; Andergassen et al. 2017), did not test whether these genes were especially enriched in given brain regions but simply asked if they were expressed (at any level) or not.

Here we address the question of whether the brain and/or specific brain circuitry is a foci for genomic imprinting by exploiting the rapidly expanding number of single-cell RNA 
sequencing (scRNA-seq) datasets and systematically investigating imprinted gene enrichment and over-representation in the murine brain. We demonstrate that imprinted genes are indeed enriched in brain relative to other adult tissues, with over-representation in the neurons of the hypothalamus, ventral midbrain, medulla, and pons. Furthermore, within these regions, imprinted genes are enriched in key, behaviourally associated, hypothalamic neurons and the midbrain/hindbrain raphe serotonin neurons. These analyses provide a robust assessment of the neural systems on which imprinted genes converge, statistically validating previous assumptions, identifying neuronal domains that have received less emphasis in earlier studies, and providing testable predictions for novel neural and behavioural phenotypes associated with specific genes and imprinted gene networks. In turn, this work sheds further light on the potential evolutionary drivers of genomic imprinting in the brain.

\section{Materials and Methods}

94 Given the breadth of single-cell datasets that are publicly available, we sought to perform a hierarchical sequence of data analysis (from a cross-organ comparison to a specific brainregion comparison) with the outcome of each level informing the data selection for the next one (see Figure 1 for summary graphic). We began at level 1 with a cross-tissue level comparison to ask would imprinted genes emerge as a brain enriched group compared to other major organs. Level 2 (whole brain level) sought to clarify that enrichment by exploring whether imprinted genes would demonstrate a regional or cell lineage specific enrichment within the brain. Level 3 (brain-region level) was then guided by the regions/cell types we found as enriched in level 2 to investigate whether those regional enrichments would be

103 further clarified at the cell subpopulation level. At each level of analysis, we aimed to be 104 unbiased by using all the datasets that fitted the aim of that level, but the availability of public scRNA-seq datasets was limited, which prevented us from exploring all avenues (for 
bioRxiv preprint doi: https://doi.org/10.1101/2020.07.27.222893; this version posted October 30, 2020. The copyright holder for this preprint (which was not certified by peer review) is the author/funder, who has granted bioRxiv a license to display the preprint in perpetuity. It is made available under aCC-BY-NC-ND 4.0 International license.

107 two or more independent datasets were used at each level to strengthen any conclusions with

Figure 1. The hierarchical set of datasets in this analysis. The hierarchical set of datasets organised by cross-tissue, whole brain and brain region level analyses. Each analysis includes the original publication and specific tissue/s analysed. White text in dark grey box indicates specifics to the analysis at that level - whether the analysis used the 'marker gene' $\log 2 \mathrm{FC}$ criteria or the relaxed $\log 2 \mathrm{FC}>0$ criterion, whether paternally and maternally expressed gene (PEG/MEG) analysis was carried out and whether the top tissue/cell-types were reported for imprinted genes.

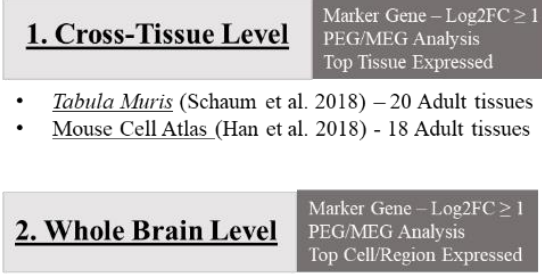

- Mouse Brain Atlas (Zeisel et al. 2018) - whole nervous system grouped by generic cell lineage, nervous system region and subpopulation identities

- Whole Mouse Brain (Ximerakis et al. 2019) - Whole Mouse Brain (minus hindbrain) grouped by specific cell lineage (24 types)

\section{$\underline{\text { 3. Specific Brain }}$ Nuclei Level}

3a) Whole Hypothalamus

- Chen et al. 2017

- Romanov et al. 2017

3b) Hypothalamic Nuclei

- Preoptic Area (Moffit et al. 2018)

- Suprachiasmatic Nucleus (Wen et al. 2020)

- Arcuate Nucleus (Campbell et al. 2017)

- Lateral Hypothalamic Area (Mickelsen et al. 2019)

convergent findings.

10915 unique datasets were analysed across the three levels and analyses were conducted on each

110 dataset independently. Data were acquired through publicly available resources or personal

111 correspondence with the authors and each dataset was filtered and normalised according to

112 the original published procedure. Table 1 details the basic parameters of each dataset. Due to

113 the high variability in sequencing technology, mouse strain, sex and age, and pipeline we

114 chose to perform our analyses independently and hence not perform direct comparisons

115 between datasets but instead look for convergent patterns of imprinted gene enrichment

116 between datasets on similar tissues/brain regions.

Table 1. Dataset specific sequencing and processing information for all datasets analysed. Datasets are organised by level of analysis and compared for single-cell sequencing protocol, Animal and Tissue processing, Cell Quality Filters used, No. of Cells in final dataset and Data Normalisation procedure followed.

\begin{tabular}{|c|c|c|c|c|c|c|}
\hline Dataset & Level & Protocol & Animal/Tissue & Cell Filter & $\begin{array}{c}\text { Cell } \\
\text { No. }\end{array}$ & Normalisation \\
\hline $\begin{array}{c}\text { Mouse Cell Atlas } \\
\text { (Han et al. 2018) }\end{array}$ & Whole Tissue & $\begin{array}{c}\text { Microwell } \\
\text {-seq }\end{array}$ & $\begin{array}{c}\text { C57BL/6J , M+F, 6-10 } \\
\text { weeks, E14.5 and neonatal }\end{array}$ & $\begin{array}{c}1500 \text { highest } \\
\text { quality cells per } \\
\text { tissue }\end{array}$ & 61,637 & $\begin{array}{c}100,000 \\
\text { transcripts log } \\
\text { transformed }\end{array}$ \\
\hline
\end{tabular}




\begin{tabular}{|c|c|c|c|c|c|c|}
\hline $\begin{array}{l}\text { Tabula Muris } \\
\text { (Schaum et al. } \\
\text { 2018) }\end{array}$ & Whole Tissue & $\begin{array}{l}\text { Smart- } \\
\text { seq2 } \\
\text { (FACs) }\end{array}$ & $\begin{array}{c}\text { C57BL/6J } 7 \text { mice } \\
(4 \mathrm{~F} / 3 \mathrm{M}), 10-15 \text { weeks, } \\
\text { virgin }\end{array}$ & $\begin{array}{c}\text { reads }>50,000 \\
\text { genes }>500\end{array}$ & 44,879 & $\ln (\mathrm{CPM}+1)$ \\
\hline $\begin{array}{c}\text { Mouse Brain } \\
\text { Atlas (Zeisel et al. } \\
\text { 2018) }\end{array}$ & Whole Brain & $\begin{array}{c}10 \mathrm{X} \\
\text { chromium }\end{array}$ & $\begin{array}{c}\mathrm{CD} 1, \mathrm{M}+\mathrm{F}, \mathrm{p} 12-30, \\
\text { week } 6 \text { and week } 8,\end{array}$ & $\begin{array}{c}600<\text { UMI } \\
1.2 \text { UMI:gene }\end{array}$ & 160,796 & $\begin{array}{c}\text { 10,000 UMI per } \\
\text { cell log } \\
\text { transformed }\end{array}$ \\
\hline $\begin{array}{c}\text { Whole Brain } \\
\text { (Ximerakis et al. } \\
\text { 2019) }\end{array}$ & Whole Brain & $\begin{array}{l}10 \mathrm{X} \\
\text { chromium }\end{array}$ & $\begin{array}{l}\text { C57BL/6J, } 16 \text { mice }(8 \\
\text { mice } 2-3 \text { months, } 8 \text { mice } \\
21-22 \text { months), whole } \\
\text { brain minus hindbrain }\end{array}$ & $\begin{array}{c}200<\mathrm{UMI}<30,000 \\
250<\text { gene }<6,000\end{array}$ & 37,089 & $\begin{array}{l}\text { 10,000 UMI per } \\
\text { cell log } \\
\text { transformed }\end{array}$ \\
\hline $\begin{array}{c}\text { Whole } \\
\text { Hypothalamus } \\
\text { (Romanov et al. } \\
\text { 2017) }\end{array}$ & $\begin{array}{c}\text { Whole } \\
\text { Hypothalamus }\end{array}$ & $\begin{array}{l}\text { Fluidigm } \\
\quad \mathrm{C} 1\end{array}$ & $\begin{array}{c}\text { C57BL/6J, M+F, 14-28 } \\
\text { days }\end{array}$ & UMI $>1500$ & 2,882 & $\begin{array}{l}\text { 10,000 UMI per } \\
\text { cell log } \\
\text { transformed }\end{array}$ \\
\hline $\begin{array}{c}\text { Whole } \\
\text { Hypothalamus } \\
\text { (Chen et al. 2017) }\end{array}$ & $\begin{array}{c}\text { Whole } \\
\text { Hypothalamus }\end{array}$ & Drop-seq & $\begin{array}{c}\text { B6D2F1 mice }(\text { C57B6 } \\
\text { female } \times \text { DBA2 male })-7 \\
\text { Female, } 8-10 \text { weeks }\end{array}$ & Genes> 2000 & 3319 & $\begin{array}{l}\text { 10,000 UMI per } \\
\text { cell log } \\
\text { transformed }\end{array}$ \\
\hline $\begin{array}{l}\text { Preoptic Area } \\
\text { (POA) (Moffitt et } \\
\text { al. 2018) }\end{array}$ & $\begin{array}{l}\text { Specific } \\
\text { Hypothalamic } \\
\text { Nucleus }\end{array}$ & $\begin{array}{l}\text { 10x } \\
\text { chromium }\end{array}$ & $\begin{array}{c}\text { C57BL/6J -6 mice (3M, } \\
\text { 3F) - 7-8 weeks, tissue } \\
\text { block spanning POA and } \\
\text { surrounding }\end{array}$ & none stated & 31,299 & $\begin{array}{l}\text { By total UMI } \\
\text { per cell, } \log 10\end{array}$ \\
\hline $\begin{array}{l}\text { Arcuate Nucleus } \\
\text { (ARC) (Campbell } \\
\quad \text { et al. 2017) }\end{array}$ & $\begin{array}{l}\text { Specific } \\
\text { Hypothalamic } \\
\text { Nucleus }\end{array}$ & Drop-seq & $\begin{array}{l}\text { C57BL/6J - 53mice }-4-12 \\
\text { weeks, virgin, } \mathrm{M}+\mathrm{F}\end{array}$ & genes $>800$ & 20,921 & $\ln (\mathrm{CPM}+1)$ \\
\hline $\begin{array}{c}\text { Lateral } \\
\text { Hypothalamic } \\
\text { Area }(\text { LHA) } \\
\text { (Mickelsen et al. } \\
\text { 2019) }\end{array}$ & $\begin{array}{l}\text { Specific } \\
\text { Hypothalamic } \\
\text { Nucleus }\end{array}$ & $\begin{array}{l}\text { Drop-seq } \\
\text { (FACs) }\end{array}$ & $\begin{array}{c}\text { C57BL/6J M+F p25-p32 } \\
\text { - LH dissected with minor } \\
\text { contamination from } \\
\text { DMH, VZI }\end{array}$ & $\begin{array}{l}\mathrm{UMI} \geq 500 \\
\text { mito }<0.4\end{array}$ & 6,944 & $\begin{array}{c}\text { By total UMI } \\
\text { per cell } \\
\text { log transformed }\end{array}$ \\
\hline $\begin{array}{l}\text { Suprachiasmatic } \\
\text { Nucleus }(\mathrm{SCN}) \\
\text { (Wen et al. 2020) }\end{array}$ & $\begin{array}{l}\text { Specific } \\
\text { Hypothalamic } \\
\text { Nucleus }\end{array}$ & $\begin{array}{l}\text { 10x } \\
\text { chromium }\end{array}$ & $\begin{array}{c}\text { C57BL/6J at timepoint } \\
\text { ZT8 }\end{array}$ & genes $>200$ & 8,679 & $\begin{array}{l}\text { By total UMI } \\
\text { per cell, log } \\
\text { transformed }\end{array}$ \\
\hline $\begin{array}{l}\text { Dorsal Raphe } \\
\text { Nucleus (DRN) } \\
\text { (Huang et al. } \\
\text { 2019) }\end{array}$ & $\begin{array}{l}\text { Monoaminergic } \\
\text { System }\end{array}$ & Drop-seq & $\begin{array}{c}\text { C57BL/6J }-8 \text { mice }(4 \mathrm{M}, \\
4 \mathrm{~F}), 8-10 \text { weeks }\end{array}$ & $\begin{array}{c}18,000>\mathrm{UMI}>500 \\
6000>\text { gene }>200 \\
\text { mito }<0.1\end{array}$ & 39,411 & $\begin{array}{l}\text { 10,000 UMI per } \\
\text { cell log } \\
\text { transformed }\end{array}$ \\
\hline $\begin{array}{l}\text { Serotonin neurons } \\
\text { of } D R N \text { and } M R N \\
\text { (Ren et al. 2019) }\end{array}$ & $\begin{array}{l}\text { Monoaminergic } \\
\text { System }\end{array}$ & $\begin{array}{l}\text { Smart- } \\
\text { seq2 }\end{array}$ & $\begin{array}{l}\text { C57BL/6J - } 14 \text { mice }(8 \mathrm{M} \text {, } \\
6 \mathrm{~F}) 40-45 \text { days }\end{array}$ & none stated & 999 & $\ln (\mathrm{CPM}+1)$ \\
\hline $\begin{array}{c}\text { E11.5 - E18.5 } \\
\text { ventral midbrain } \\
\text { (La Manno et al. } \\
2016)\end{array}$ & $\begin{array}{l}\text { Monoaminergic } \\
\text { System }\end{array}$ & $\begin{array}{l}\text { Fluidigm } \\
\quad \mathrm{C} 1\end{array}$ & $\begin{array}{c}\text { CD1, E11.5 - E18.5 - } 271 \\
\text { embryos }\end{array}$ & $\begin{array}{c}2000>\mathrm{UMI}>26,00 \\
0\end{array}$ & 1,907 & $\begin{array}{l}\text { By total UMI } \\
\text { per cell, log } \\
\text { transformed }\end{array}$ \\
\hline $\begin{array}{c}\text { Midbrain } \\
\text { Dopamine } \\
\text { Neurons (Tiklová } \\
\text { et al. 2019) }\end{array}$ & $\begin{array}{l}\text { Monoaminergic } \\
\text { System }\end{array}$ & $\begin{array}{l}\text { Smart- } \\
\text { seq2 }\end{array}$ & $\begin{array}{c}\text { C57BL/6NRj mice, } \mathrm{M}+\mathrm{F}, \\
\text { Pitx3 expressing cells } \\
\text { from E13.5, E15.5, E18.5, } \\
\text { P1, P7, P90 }\end{array}$ & $\begin{array}{c}\text { Norm reads } \\
>100,000 \\
>15 \% \text { of all genes }\end{array}$ & 1,106 & RPKM \\
\hline $\begin{array}{c}\text { Whole Brain } \\
\text { Dopamine (Hook } \\
\text { et al. 2018) }\end{array}$ & $\begin{array}{l}\text { Monoaminergic } \\
\text { System }\end{array}$ & $\begin{array}{l}\text { Smart- } \\
\text { seq2 }\end{array}$ & $\mathrm{C} 57 \mathrm{BL} / 6 \mathrm{~J}$ at E15.5 and P7 & $\begin{array}{c}2000<\text { genes } \\
<10,000 \\
1000>\text { RNA } \\
>40,000\end{array}$ & 396 & $\log (\mathrm{FPKM}+1)$ \\
\hline
\end{tabular}

117 Once processed, each dataset was run through the same basic workflow (see below and

118 Figure 2), with minor adjustments laid out for each dataset detailed in the Supplemental

119 Methods. The aim of the analysis differed slightly between the levels. Level 1 and level 2

120 analyses represented cells from a variety of organs, regions and cell-types and, in line with

121 this cellular diversity, our analysis followed a procedure appropriate for identifying marker

122 genes, meaning we were looking for distinct imprinted gene enrichment and the tissues they

123 displayed 'marker' like expression for. Level 3 analysis featured many independent analyses

124 with a reduced scope (i.e. one specific region or sub-region of the brain and often a single 
cell-type). We did not anticipate imprinted genes to populate the marker genes at this level and hence our analyses focused on identifying patterns of upregulated genes looking for cell-

127 types that imprinted genes are convergently upregulated in above background, using this

128 relaxed criterion for upregulation.

\section{Custom Imprinted Gene List}

130 The gene list for the analysis was based on the list of murine imprinted genes recently published 131 in Tucci et al. (2019). 119 imprinted genes were chosen for the analysis (Supplemental Table

132 S1) consisting of canonical protein-coding and long noncoding RNA imprinted genes, the 133 criteria for inclusion was those genes with at least two independent demonstrations of their

134 POE status. The only exceptions to multiple independent demonstrations of a POE were four genes (Bmf, B3gnt2, Ptk2, Gm16299) identified by (Perez et al. 2015) where a POE was validated for 16 brain regions and 7 adult tissues. Small non-coding RNAs such as micro-RNAs (miRs) and small nucleolar RNAs (snoRNAs), which represent $\sim 10 \%$ of identified imprinted genes, were excluded from the analysis as their sequences were not detected/subsumed by

139 larger transcripts in the majority of the datasets. Another caveat with short-read RNA-seq

140 libraries is that much of the expression data for a given transcription unit cannot discriminate differentially imprinted isoforms, such as the Gnas locus, as most of the reads mapping to the

142 locus will map to shared exons. Indeed, only Gnas and Nespas are consistently distinguished

143 from this locus.

\section{Basic Workflow}

145 Data were downloaded in the available form provided by the original authors (either raw or 146 processed) and, where necessary, were processed (filtered, batch-corrected and normalized)

147 to match the author's original procedure. Cell quality filters were specific to each dataset and

148 summarised in Table 1. A consistent filter, to keep all genes expressed in at least 20 cells, 149 was applied to remove genes unlikely to play a functional role due to being expressed in only 
150 a few cells. Datasets from the brain were analysed both at the global cell level (neuronal and

151 non-neuronal cells) and neuron specific level (only cells classified as neurons) with genes

152 filtered for the $\geq 20$ cell expression at each level before subsequent analysis. Cell identities

153 were supplied using the outcome of cell clustering carried out by the original authors, so that

154 each cell included in the analysis had a cell-type or tissue-type identity. This was acquired as metadata supplied with the dataset or as a separate file from personal correspondence with the author. Unless otherwise stated, all cells that were used to originally cluster the subpopulations were included in this analysis. In all cases this involved data from both sexes and from all post-natal ages (e.g. both young and old mice from Ximerakis et al. 2019).

159 Embryonic and post-natal tissue was never pooled to contribute to the same cell populations.

160 Positive differential expression between identity groups were carried out using one-sided

161 Wilcoxon rank-sum tests (assuming the average expression of cells within the current identity

162 group is 'greater' than the average of cells from all other groups). The test was performed

163 independently for each gene and for each identity group vs. all other groups. The large

164 number of $p$ values were corrected for multiple comparisons using a horizontal Benjamini-

165 Hochberg correction, creating $q$ values. Fold-change (FC) values, percentage expression within the identity group and percentage expressed within the rest were also calculated. We

167 considered genes to be significantly positively differentially expressed (significantly

168 upregulated) in a group compared to background expression if it had a $q \leq 0.05$. In addition,

169 for level 1 and level 2 analysis, the criteria for upregulated genes included demonstrating a

170 Log2FC value of 1 or larger (i.e. 2-fold-change or larger), which selects for genes across a 171 variety of tissue, cell-types and brain regions with distinctive upregulation, akin to a marker 172 gene. Once the analysis was restricted to cell subpopulations within a specific region of the 173 brain (i.e. level 3), the additional criteria for upregulation was relaxed to demonstrating just a 174 positive Log2FC (i.e. the gene has a higher expression in this cell type than background). 
175 This was mainly because we were

176 not expecting imprinted genes to

177 be 'markers' of individual cell

178 types at this level, but our aim was

179 to identify enriched expression

180 profiles for them. This

181 additionally ensures consistent

182 criteria for enrichment within

183 levels, allowing meaningful

184 comparison.

185 The same custom list of imprinted included as long as the gene
Figure 2. Basic workflow schematic. Single Cell Expression Matrices were acquired through publicly available depositories. Data were processed according to the author's original specifications and all genes were required to be expressed in 20 or more cells. Cell population identities were acquired from the author's original clustering. Positive differential gene expression was calculated via Wilcoxon Rank-Sum Test. Upregulated genes were considered as those with $q \leq 0.05$ and a Log2FC $\geq 1$ for analysis levels 1 and 2, while this criterion was relaxed to Log2FC $>0$ for level 3. Our custom imprinted gene list was used to select out upregulated genes that were imprinted and two different enrichment analyses were carried out, over-representation analysis via Fisher's Exact Test and Gene Set Enrichment Analysis via Liger algorithm (Subramanian et al. 2005,chttps://github.com/JEFworks/liger). Additionally, Level 1 and Level 2 Analyses repeated the enrichment analyses with lists of just MEGs and PEGs

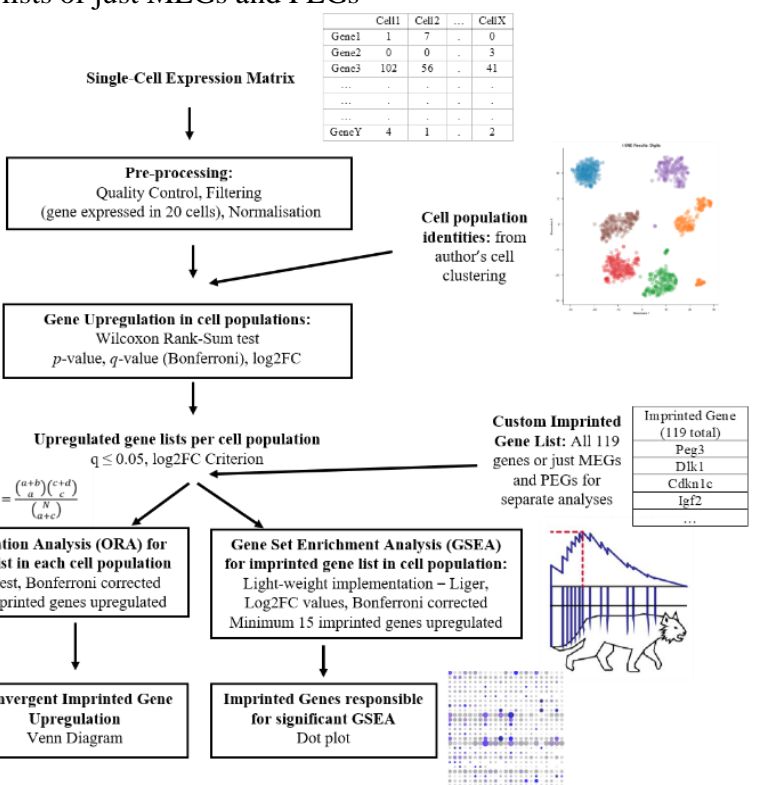

passed the 20-cell filter. The first statistical analysis for enrichment was an Over-

Representation Analysis (ORA) using a one-way Fisher's Exact Test ('fisher.test' function in R core package 'stats $\mathrm{v} 3.6 .2$ '). The aim was to assess whether the number of imprinted genes considered to be upregulated as a proportion of the total number of imprinted genes in the dataset (passing the 20-cell filter) was statistically higher than would be expected by chance when compared to the total number of upregulated genes as a proportion of the overall number of genes in the dataset (passing the 20-cell filter). To limit finding over-represented identity groups with only a few upregulated imprinted genes, an identity group was required to have $\geq 5 \%$ of the total number of imprinted genes upregulated for ORA to be conducted. Subsequent p-values for all eligible identity groups were corrected using a Bonferroni 
correction. This provided a measure of whether imprinted genes are expressed above expectation (the expression pattern of a random gene list) in particular identity groups.

202 Venn diagrams of the upregulated imprinted genes making up over-represented identity

203 groups across datasets (within a level) are also reported. Full lists of upregulated imprinted

204 genes can be found in the 'Upregulated_IGs.csv' file for each analysis in the repository

\section{5 (https://osf.io/jx7kr/).}

206 To further examine the presence of imprinted genes within tissues, and to provide a different

207 perspective to over-representation, we conducted a Gene-Set Enrichment Analysis (GSEA) of 208 imprinted genes using a publicly available, light-weight implementation of the GSEA

209 algorithm (Subramanian et al. 2005) in R (https://github.com/JEFworks/liger) in a manner

210 similar to Moffitt et al. (2018). The GSEA was conducted using Log2FC values of

211 statistically significant upregulated genes and is a more conservative measure since it tests

212 whether imprinted genes are enriched in the stronger markers of a group (the genes with the

213 highest fold change for a group vs. the rest). Groups analysed were selected as having an

214 minimum number of upregulated imprinted genes to measure enrichment for (minimum of

21515 as suggested by the GSEA user guide (https://www.gsea-msigdb.org/gsea/doc/GSEAUser

216 GuideFrame.html) and having an average fold change of the upregulated imprinted genes

217 greater than the average fold change of the rest of the upregulated genes for that tissue.

218 Again, multiple $\mathrm{p}$ values generated from GSEA were corrected using a Bonferroni correction.

219 Graphical representations of significant GSEA's (post-correction) are included in the main

220 text or Appendix B, all other graphs can be found in the repository (https://osf.io/jx $7 \mathrm{kr} /)$. To

221 further elucidate the genes responsible for significant GSEA's, dot plots of the imprinted

223 expression and Log2FC mapped to size and colour of the dots respectively. If no cell

224 populations met these criteria, GSEA was not run and were not included in the results. 
The absolute number of IGs top-expressed in a tissue/cell-type were also reported for analyses in level 1 and level 2, since these analyses included a variety of cell-types and tissues which may demonstrate meaningful clustering of the highest normalised expression values.

229 For level 1 and level 2 analyses, we also carried out parent-of-origin specific analyses. Much 230 interest exists concerning the different functions maternally expressed genes (MEGs) and paternally expressed genes (PEGs) plays and we thought it would be valuable to run the large-scale enrichment analyses (level 1 and level 2) using separate lists of PEGs and MEGs. The imprinted gene list was divided into MEGs and PEGs and the analyses detailed above were run separately for these two gene groups. For imprinted genes with known parent-oforigin variability based on tissue type (Igf2 and Grb10), the parent-of-origin characterisation of these genes was changed accordingly.

237 All graphical representations and statistical analyses were conducted using R 3.6.2 (Team 2013) in RStudio (Team 2015). All processing scripts are available at

239 https://github.com/MJHiggs/IG-Single-Cell-Enrichment. All data files are available at the following Open Science Framework repository (https://osf.io/jx7kr/). All summary diagrams and Venn diagrams (Figures 1:4, 6:8, 10:11) were created with BioRender.com.

\section{Results}

244 The hierarchical order of enrichment testing, as demonstrated in Figure 1, began with 245 comparisons of whole brain imprinted gene enrichment vs. other adult and developing tissues 246 to ask whether imprinted genes were statistically enriched in the brain.

\section{1) Whole tissue level analysis}

$248 \quad 1.1$ Imprinted gene are over-represented in the brain at whole tissue level analysis 
bioRxiv preprint doi: https://doi.org/10.1101/2020.07.27.222893; this version posted October 30, 2020. The copyright holder for this preprint (which was not certified by peer review) is the author/funder, who has granted bioRxiv a license to display the preprint in perpetuity. It is made available under aCC-BY-NC-ND 4.0 International license.

249 The Mouse Cell Atlas (MCA) (Han et al. 2018) and the Tabula Muris (TM) (Schaum et al.

250 2018) are single cell compendiums of $\sim 20$, overlapping but not identical, mouse organs (the

251 brain was included in both). These compendiums create a snapshot of gene expression across

252 adult tissues to assess imprinted gene enrichment.

253 Analysis of the MCA and TM revealed convergence in the tissues in which imprinted genes

are over-represented. In the MCA adult tissue dataset, there was an over-representation of

imprinted genes in the pancreas, brain, bladder and uterus (Table 2).

Table 2. Imprinted gene over-representation in MCA adult tissues (Han et al. 2018). Identity -

Tissue identities for the cells used in analysis; Up Reg - number of upregulated genes with $q \leq 0.05$ and $\log 2 \mathrm{FC} \geq$ 1 (total number of genes in the dataset in brackets); $I G$ - number of imprinted genes upregulated with $q \leq 0.05$ and $\log 2 \mathrm{FC} \geq 1$ (total number of IGs in the dataset in brackets); ORA $p-p$ value from over representation analysis on groups with minimum 5\% of total IGs; ORA $q$ - Bonferroni corrected $p$ value from ORA; Mean FC IG - mean fold change for upregulated imprinted genes; Mean FC Rest - mean fold change for all other upregulated genes: Top Tissue IGs - Sum of IGs with highest mean expression value for that identity group.

\begin{tabular}{|c|c|c|c|c|c|c|c|}
\hline Identity & $\begin{array}{c}\text { Up Reg } \\
(20,547)\end{array}$ & $\begin{array}{l}\text { IG } \\
(97)\end{array}$ & ORA $p$ & ORA $q$ & $\begin{array}{c}\text { Mean FC } \\
\text { IG }\end{array}$ & $\begin{array}{c}\text { Mean FC } \\
\text { Rest }\end{array}$ & $\begin{array}{c}\text { Top Tissue } \\
\text { IGs }\end{array}$ \\
\hline Pancreas & 2737 & 42 & $1.54 \mathrm{E}-13$ & $\underline{1.85 \mathrm{E}-12}$ & 8.74 & 10.32 & 22 \\
\hline Brain & 3401 & 34 & 4.37E-06 & 5.24E-05 & 8.76 & 125.00 & 19 \\
\hline Bladder & 3184 & 29 & 0.000167 & $\underline{0.002001}$ & 4.45 & 8.51 & 8 \\
\hline Uterus & 2568 & 22 & 0.002818 & $\underline{0.033816}$ & 4.66 & 8.46 & 7 \\
\hline Kidney & 1714 & 10 & 0.267788 & 1 & 13.76 & 182.89 & 5 \\
\hline Liver & 1739 & 8 & 0.559405 & 1 & 4.55 & 80.51 & 3 \\
\hline Lung & 1204 & 8 & 0.192845 & 1 & 3.82 & 151.29 & 4 \\
\hline Ovary & 2219 & 13 & 0.223000 & 1 & 7.46 & 11.27 & 5 \\
\hline Small Intestine & 1726 & 5 & 0.909559 & 1 & 7.99 & 217.84 & 2 \\
\hline Stomach & 1821 & 7 & 0.747992 & 1 & 4.24 & 88.60 & 3 \\
\hline Testis & 5212 & 14 & 0.995849 & 1 & 27.04 & 5058.36 & 10 \\
\hline Thymus & 1805 & 6 & 0.851156 & 1 & 2.78 & 6.76 & 2 \\
\hline Bone Marrow & 1098 & 2 & - & - & 5.31 & 4.46 & 1 \\
\hline Mammary Gland Virgin & 905 & 4 & - & - & 3.70 & 4.05 & 0 \\
\hline Muscle & 1130 & 4 & - & - & 8.64 & 15.34 & 3 \\
\hline Peripheral Blood & 1147 & 3 & - & - & 3.78 & 3.57 & 0 \\
\hline Prostate & 369 & 0 & - & - & 0.00 & 478.10 & 0 \\
\hline Spleen & 1507 & 1 & - & - & 4.90 & 4.83 & 1 \\
\hline
\end{tabular}

256 In the Tabula Muris analysis (Table 3), there was a significant over-representation in the brain

257 (non-myeloid) cells, pancreas, bladder and the muscle-based tissues - diaphragm, trachea, and

limb muscles. No tissue at this level showed a significant GSEA.

Table 3. Imprinted gene over-representation in Tabula Muris adult tissues (Schaum et al. 2018). Identity - Tissue identities for the cells used in analysis; Up Reg - number of upregulated genes with $q \leq 0.05$ and $\log 2 \mathrm{FC} \geq 1$ (total number of genes in the dataset in brackets); $I G$ - number of imprinted genes upregulated with $q \leq 0.05$ and Log2FC $\geq 1$ (total number of IGs in the dataset in brackets); ORA $p-p$ value from over representation analysis on groups with minimum 5\% of total IGs; ORA $q$ - Bonferroni corrected $p$ value from ORA; Mean FC IG - mean fold change for upregulated imprinted genes; Mean FC Rest - mean fold change for all other upregulated genes; GSEA $p-p$ value from Gene Set Enrichment Analysis for identity groups with 15+ IGs and Mean FC IG > Mean FC Rest; GSEA $q$ - Bonferroni corrected $p$ values from GSEA; Top Tissue IGs - Sum of IGs with highest mean expression value for that identity group.

\begin{tabular}{|c|c|c|c|c|c|c|c|c|c|}
\hline Identity & $\begin{array}{c}\text { Up Reg } \\
(\mathbf{2 2 , 1 1 2})\end{array}$ & $\begin{array}{c}\text { IG } \\
(\mathbf{1 0 7})\end{array}$ & $\begin{array}{c}\text { ORA } \\
\boldsymbol{p}\end{array}$ & $\begin{array}{c}\text { ORA } \\
\boldsymbol{q}\end{array}$ & $\begin{array}{c}\text { Mean FC } \\
\text { IG }\end{array}$ & $\begin{array}{c}\text { Mean FC } \\
\text { Rest }\end{array}$ & $\begin{array}{c}\text { GSEA } \\
\boldsymbol{p}\end{array}$ & $\begin{array}{c}\text { GSEA } \\
\boldsymbol{q}\end{array}$ & $\begin{array}{c}\text { Top } \\
\text { Tissue } \\
\text { IGs }\end{array}$ \\
\hline Diaphragm & 426 & 19 & $1.99 \mathrm{E}-13$ & $\underline{\mathbf{2 . 5 8 E}-12}$ & 6.49 & 4.90 & 0.2159 & 0.4318 & 4 \\
Limb Muscle & 783 & 24 & $3.32 \mathrm{E}-13$ & $\underline{\mathbf{4 . 3 2 E}-12}$ & 9.02 & 5.34 & 0.0661 & 0.1322 & 8
\end{tabular}


bioRxiv preprint doi: https://doi.org/10.1101/2020.07.27.222893; this version posted October 30, 2020. The copyright holder for this preprint (which was not certified by peer review) is the author/funder, who has granted bioRxiv a license to display the preprint in perpetuity. It is made available under aCC-BY-NC-ND 4.0 International license.

\begin{tabular}{|c|c|c|c|c|c|c|c|c|c|}
\hline Pancreas & 4154 & 43 & $2.17 \mathrm{E}-07$ & $\underline{2.82 \mathrm{E}-06}$ & 12.52 & 12.88 & - & - & 29 \\
\hline Trachea & 2024 & 25 & 9.49E-06 & $\overline{\mathbf{0 . 0 0 0 1 2 3}}$ & 3.81 & 4.82 & - & - & 5 \\
\hline $\begin{array}{l}\text { Brain (Non- } \\
\text { Myeloid) }\end{array}$ & 3122 & 31 & $5.09 \mathrm{E}-05$ & $\underline{0.000661}$ & 12.16 & 14.14 & - & - & 14 \\
\hline Bladder & 3354 & 31 & 0.000196 & $\underline{0.002549}$ & 3.30 & 5.34 & - & - & 16 \\
\hline Fat & 1273 & 12 & 0.020121 & 0.261578 & 3.46 & 3.72 & - & - & 1 \\
\hline Heart & 1113 & 10 & 0.043228 & 0.561958 & 2.87 & 5.16 & - & - & 0 \\
\hline $\begin{array}{l}\text { Mammary } \\
\text { Gland }\end{array}$ & 1836 & 12 & 0.176572 & 1 & 3.52 & 5.27 & - & - & 3 \\
\hline Liver & 1819 & 7 & 0.786891 & 1 & 6.19 & 54.80 & - & - & 3 \\
\hline Tongue & 4341 & 15 & 0.948735 & 1 & 4.15 & 7.40 & - & - & 8 \\
\hline Aorta & 4444 & 14 & 0.978213 & 1 & 7.47 & 26.91 & - & - & 2 \\
\hline Large Intestine & 5399 & 11 & 0.999941 & 1 & 5.95 & 13.00 & - & - & 5 \\
\hline $\begin{array}{c}\text { Brain } \\
\text { (Myeloid) }\end{array}$ & 1032 & 5 & - & - & 3.39 & 6.80 & - & - & 2 \\
\hline Kidney & 604 & 3 & - & - & 24.94 & 22.84 & - & - & 1 \\
\hline Lung & 924 & 2 & - & - & 2.73 & 5.65 & - & - & 0 \\
\hline Marrow & 1969 & 5 & - & - & 7.65 & 5.26 & - & - & 4 \\
\hline Skin & 1625 & 4 & - & - & 4.15 & 8.42 & - & - & 1 \\
\hline Spleen & 627 & 1 & - & - & 4.63 & 4.32 & - & - & 0 \\
\hline Thymus & 700 & 4 & - & - & 3.46 & 7.56 & - & - & 1 \\
\hline
\end{tabular}

259 Separating the analysis for MEGs and PEGs (Supplemental Table S2a, S2b, S3a and S3b)

260 revealed a similar pattern of enrichment in both the datasets (Figure 3). Focusing on the brain,

\section{Figure 3. Level 1 cross-tissue comparison summary graphics.}

3a) Venn diagram of upregulated imprinted genes in the brain in Mouse Cell Atlas and in the brain (non-myeloid) in the Tabula Muris. Imprinted genes are listed which show significant upregulation $(q \leq 0.05$ and $\log 2 \mathrm{FC} \geq 1)$ in the tissues. Although these tissues are not identical, these were the two brain associated over-representations in the enrichment analysis. Parental-bias is indicated by colour (MEG - red, PEG - blue). From the 119 imprinted genes in the gene list, only 92 were common to both analyses (i.e. successfully sequenced and passed gene quality control filters). 34 imprinted genes were upregulated in the brain in the MCA and 31 genes in the TM. Genes in common from the two analyses are presented in bold and totalled in each section of the Venn Diagram, while genes found upregulated in one analysis but not available in the other analysis are included in

small font and the number indicated in brackets.

3b) Tissues with over-representation in MCA (Han et al. 2018). Coloured tissues with bold labels were over-represented tissues using all imprinted genes, tissues with a blue circle behind were over-represented for PEGS alone and red circles represent the same for MEGs.

3c) Tissues with over-representation in Tabula Muris (Schaum et al. 2018). Coloured tissues with bold labels were over-represented tissues using all imprinted genes, tissues with a blue circle behind were over-represented for PEGS alone and red circles represent the same for MEGs.

B

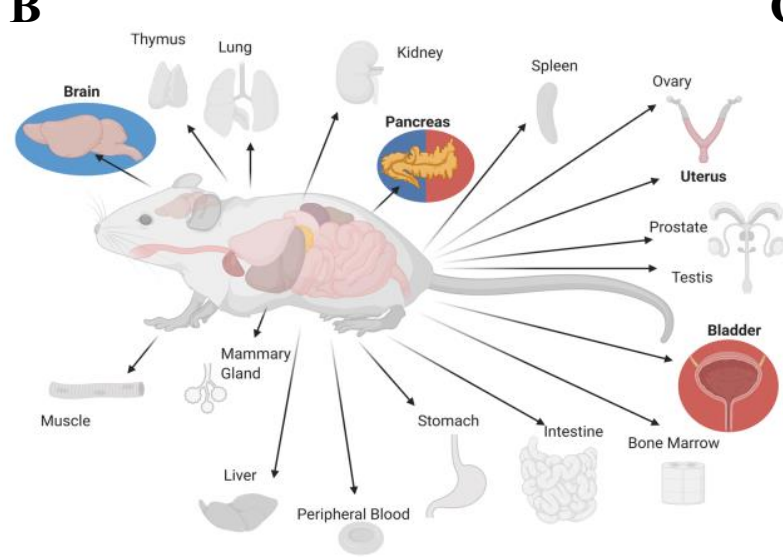

A

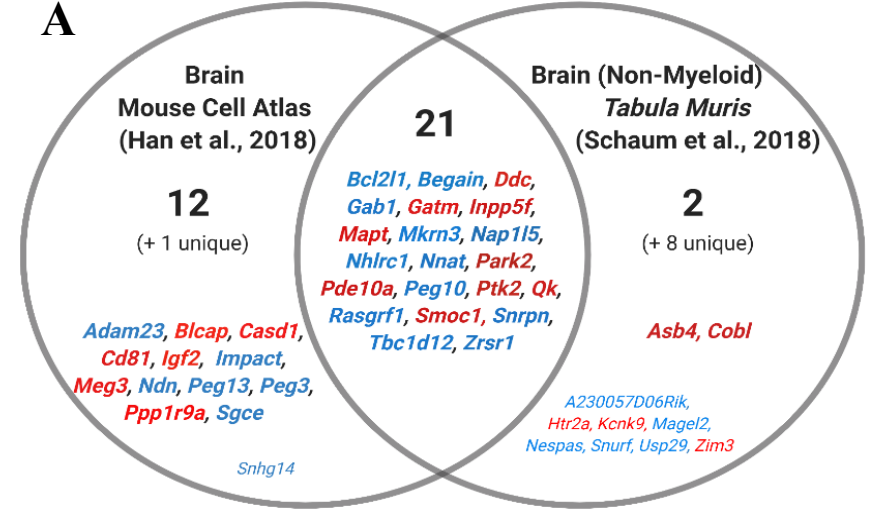

C

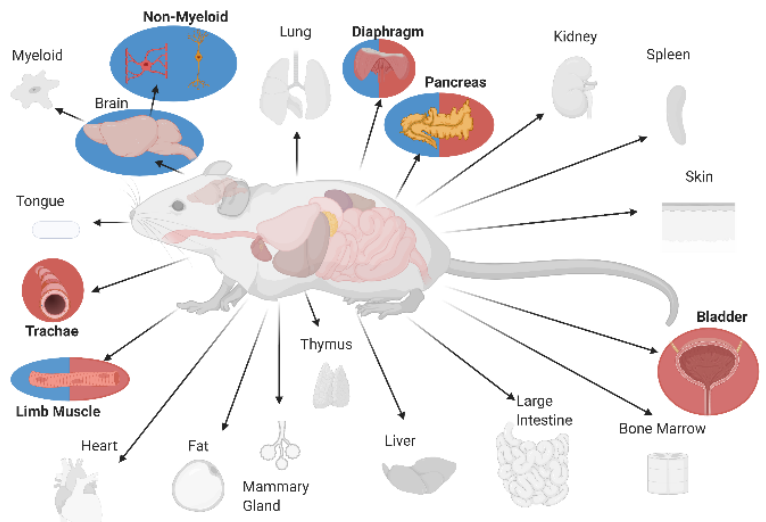


261 PEGs were over-represented in both datasets (MCA $\left.-q=4.51 \times 10^{-6}, T M-q=0.0002\right)$ and

262 MEGs were not (MCA $-q=0.97, T M-q=1$ ). PEGs were also over-represented in the

263 diaphragm $(q=0.0006)$, limb muscle $\left(q=9.63 \times 10^{-5}\right)$ and pancreas $\left(\mathrm{MCA}-q=1.91 \times 10^{-5}, T M\right.$

$264-q=0.0004)$, with a significant GSEA in the MCA pancreas $(p=0.02$, Appendix B1). While

265 MEGs were over-represented in the bladder (MCA $-q=0.002, T M-q=0.021$ ), the pancreas

266 (MCA $\left.-q=1.51 \times 10^{-7}, T M-q=0.03\right)$ and in the three muscular tissues of the Tabula Muris

267 (diaphragm $-q=1.44 \times 10^{-8}$, limb muscle $-q=1.66 \times 10^{-7}$, trachea $-q=0.003$ ).

268 In summary, across adult tissues, imprinted genes were convergently over-represented in the

269 pancreas, bladder and the brain. The convergence of imprinted genes upregulated in the brain

270 compared to other adult organs within the two compendiums is represented in Figure 3.

\section{2. Whole Brain level analysis}

272 Having found an over-representation in the brain at level 1, we next sought to test whether

273 imprinted genes would demonstrate a cell-type or regional enrichment within the whole brain.

$274 \quad 2 \mathrm{i})$ Imprinted genes are enriched in neurons and neuroendocrine cells

275 We first analysed Ximerakis et al.’s (2019) dataset, in which cells were grouped from the whole

276 mouse brain (minus the hindbrain) into major cell classes according to cell lineage. Imprinted

277 genes were over-represented in neuroendocrine cells and mature neurons (Table 4).

Table 4. Imprinted gene over-representation in neural lineage types (Ximerakis et al. 2019). Identity - Cell Lineage identities for the cells used in analysis; $U p$ Reg - number of upregulated genes with $q \leq 0.05$ and Log2FC $\geq 1$ (total number of genes in the dataset in brackets); $I G$ - number of imprinted genes upregulated with $q \leq 0.05$ and Log2FC $\geq 1$ (total number of IGs in the dataset in brackets); ORA $p-p$ value from over representation analysis on groups with minimum 5\% of total IGs; ORA $q$ - Bonferroni corrected $p$ value from ORA; Mean FC IG - mean fold change for upregulated imprinted genes; Mean FC Rest - mean fold change for all other upregulated genes; GSEA $p-p$ value from Gene Set Enrichment Analysis for identity groups with 15+ IGs and Mean FC IG > Mean FC Rest; GSEA $q$ - Bonferroni corrected $p$ values from GSEA; Top Cell IGs - Sum of IGs with highest mean expression value for that identity group.

\begin{tabular}{|c|c|c|c|c|c|c|c|c|c|}
\hline Identity (Abbr) & $\begin{array}{c}\text { Up Reg } \\
(\mathbf{1 4 , 6 6 1 )}\end{array}$ & $\begin{array}{c}\text { IG } \\
\mathbf{( 8 8})\end{array}$ & ORA $\boldsymbol{p}$ & $\mathbf{\text { ORA } \boldsymbol { q }}$ & $\begin{array}{c}\text { Mean } \\
\text { FC } \\
\text { IG }\end{array}$ & $\begin{array}{c}\text { Mean } \\
\text { FC } \\
\text { Rest }\end{array}$ & GSEA $\boldsymbol{p}$ & $\begin{array}{c}\text { GSEA } \\
\boldsymbol{q}\end{array}$ & $\begin{array}{c}\text { Top } \\
\text { Cell } \\
\text { IGs }\end{array}$ \\
\hline $\begin{array}{c}\text { Neuroendocrine cells (NendC) } \\
\begin{array}{c}\text { Mature Neurons (all types) } \\
\text { (mNEUR) }\end{array}\end{array}$ & 4234 & 48 & $3.84 \mathrm{E}-07$ & $\underline{\mathbf{6 . 9 2 E}-\mathbf{0 6}}$ & 16.34 & 5.49 & $9.00 \mathrm{E}-04$ & $\underline{\mathbf{0 . 0 0 3 6}}$ & 32 \\
$\begin{array}{c}\text { Vascular and leptomeningeal } \\
\text { cells (VLMC) }\end{array}$ & 1735 & 19 & 0.006444 & 0.115995 & 85.82 & 12.22 & 0.0946 & 0.3784 & 4 \\
\hline $\begin{array}{c}\text { Tanycytes (TNC) } \\
\text { Arachnoid barrier cells (ABC) }\end{array}$ & 1698 & 18 & 0.011174 & 0.201139 & 6.55 & 8.67 & - & - & 7 \\
\hline $\begin{array}{c}\text { Oligodendrocyte precursor cells } \\
\text { (OPC) }\end{array}$ & 1549 & 12 & 0.216078 & 1 & 3.06 & 7.43 & - & - & 2 \\
\hline Pericytes (PC) & 1764 & 13 & 0.256801 & 1 & 7.95 & 7.59 & - & - & 3 \\
\hline
\end{tabular}




\begin{tabular}{|c|c|c|c|c|c|c|c|c|c|}
\hline $\begin{array}{l}\text { Choroid plexus epithelial cells } \\
\text { (CPC) }\end{array}$ & 2873 & 20 & 0.266209 & 1 & 79.24 & 23.94 & 0.1717 & 0.6868 & 9 \\
\hline Oligodendrocytes (OLG) & 1124 & 8 & 0.361824 & 1 & 3.95 & 10.45 & - & - & 5 \\
\hline $\begin{array}{l}\text { Vascular smooth muscle cells } \\
\text { (VSMC) }\end{array}$ & 3133 & 20 & 0.418819 & 1 & 7.95 & 6.85 & 0.1622 & 0.6488 & 2 \\
\hline Immature Neurons (immN) & 713 & 5 & 0.427092 & 1 & 3.34 & 5.90 & - & - & 0 \\
\hline $\begin{array}{l}\text { Olfactory ensheathing glia } \\
\text { (OEG) }\end{array}$ & 1195 & 8 & 0.428082 & 1 & 8.42 & 23.85 & - & - & 2 \\
\hline $\begin{array}{l}\text { Hemoglobin-expressing vascular } \\
\text { cells (Hb_VC) }\end{array}$ & 1930 & 11 & 0.620935 & 1 & 5.07 & 6.01 & - & - & 3 \\
\hline Endothelial cells (EC) & 1496 & 8 & 0.686994 & 1 & 5.19 & 8.25 & - & - & 0 \\
\hline $\begin{array}{c}\text { Astrocyte-restricted precursors } \\
\text { (ARP) }\end{array}$ & 1853 & 10 & 0.688635 & 1 & 3.88 & 4.58 & - & - & 1 \\
\hline Ependymocytes (EPC) & 3429 & 17 & 0.849270 & 1 & 15.45 & 54.05 & - & - & 3 \\
\hline $\begin{array}{l}\text { Neuronal-restricted precursor } \\
\text { (NRP) }\end{array}$ & 2458 & 9 & 0.969946 & 1 & 2.75 & 13.07 & - & - & 0 \\
\hline Hypendymal cells (HypEPC) & 1843 & 6 & 0.972273 & 1 & 12.15 & 21.45 & - & - & 3 \\
\hline Astrocytes & 1430 & 4 & - & - & 2.57 & 6.20 & - & - & 0 \\
\hline Neural stem cells & 1202 & 4 & - & - & 8.29 & 4.02 & - & - & 0 \\
\hline Dendritic cells & 1493 & 3 & - & - & 3.61 & 14.66 & - & - & 0 \\
\hline Microglia & 1452 & 3 & - & - & 18.96 & 17.95 & - & - & 3 \\
\hline Macrophages & 1275 & 2 & - & - & 2.96 & 19.89 & - & - & 0 \\
\hline Monocytes & 1150 & 2 & - & - & 10.53 & 25.45 & - & - & 1 \\
\hline Neutrophils & 607 & 1 & - & - & 6.48 & 89.29 & - & - & 0 \\
\hline
\end{tabular}

278 Neuroendocrine cells were defined as a heterogeneous cluster, containing peptedergic neurons

279 and neurosecretory cells (e.g. Avp and $O x t$ expressing), expressing neuronal marker genes (e.g.

280 Syt1 and Snap25) but critically having unique expression of Baiap3 which plays an important

281 role in the regulation of exocytosis in neuroendocrine cells. GSEA additionally showed that

282 the imprinted genes were enriched in the strong markers (i.e. amongst the genes with the

283 highest fold change values) for neuroendocrine cells only (Figure 4). 32 imprinted genes had

284 their highest expression in the neuroendocrine cells as compared to one imprinted gene in the

285 other mature neurons. The MEG/PEG analysis (Supplemental Table S4a and S4b) for this

286 dataset found that PEGs were novelly over-represented in tanycytes $(q=0.009)$ while also

287 demonstrating over-representation in mature neurons $(q=0.01)$ and neuroendocrine cells $(q=$

$\left.2881.86 \times 10^{-5}\right)$ and a significant GSEA in the latter also $\left(p=9 \times 10^{-4}\right.$, Appendix B2). In contrast,

289 MEGs were novelly over-represented in Arachnoid barrier cells $(q=0.019)$ and Vascular and

290 Leptomeningeal cells $(q=0.037)$ with no significant ORA or GSEA in the neurons or

291 neuroendocrine cells.

292 The second dataset at this level was Zeisel et al.'s (2018) Mouse Brain Atlas (MBA) and it

293 allowed a much deeper investigation of nervous system enrichment with sequencing of the 
bioRxiv preprint doi: https://doi.org/10.1101/2020.07.27.222893; this version posted October 30, 2020. The copyright holder for this preprint (which was not certified by peer review) is the author/funder, who has granted bioRxiv a license to display the preprint in perpetuity. It is made available under aCC-BY-NC-ND 4.0 International license.

Figure 4. Imprinted gene GSEA for genes upregulated in neuroendocrine cells. Right GSEA graph - In the analysis, genes are sorted by strength by which they mark this neuronal cluster (sorted by Log2FC values) indicated by the bar (bottom). The genes are arrayed left (strongest marker) to right and blue lines mark where imprinted genes fall on this array. The vertical axis indicates an accumulating weight, progressing from left to right and increasing or decreasing depending on whether the next gene is an imprinted gene or not. The $p$-value represents the probability of observing the maximum value of the score (red dashed line) if the imprinted genes are distributed randomly along the horizontal axis. The $q$-value for this analysis was significant at 0.0036. Bottom Dot Plot - Upregulated imprinted genes in neuroendocrine cells, separated by MEGs and PEGs, were plotted across all cell types with 5 or more imprinted genes upregulated in Ximerakis et al. 2019 (Abbr. in Table 4). Size of points represented absolute mean expression; colour represented the size of the Log2FC value for neuroendocrine cells vs. all other cells.

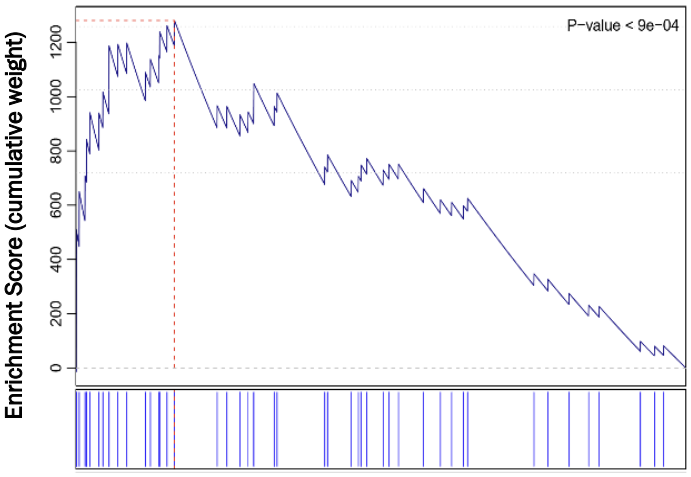

Sorted Genes (by descending Log2FC)

PEGs

MEGs
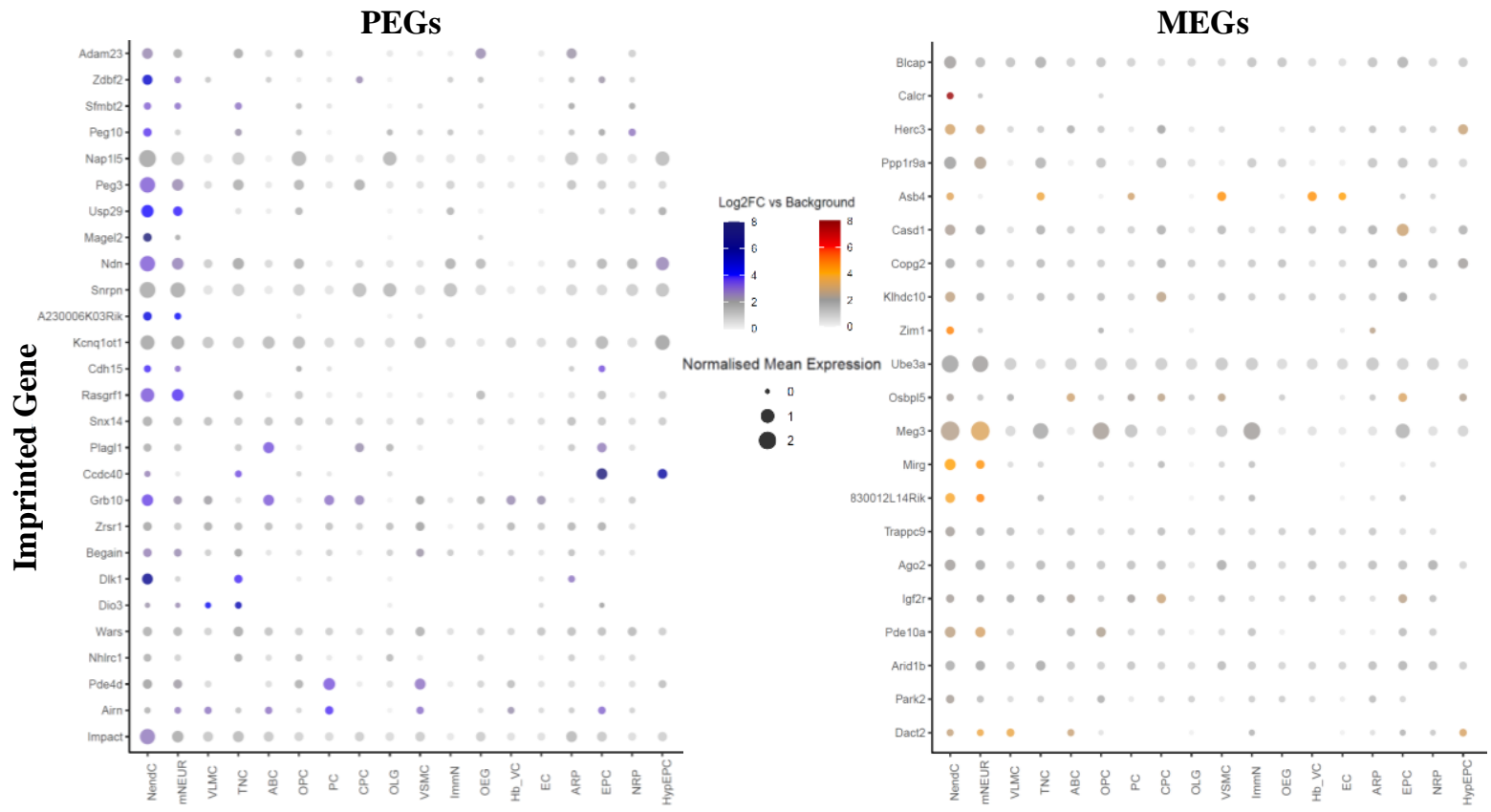

Cell Identity (Whole Brain)

entire murine nervous system and identifying cells by both brain region and cell type.

295 Concordant with the previous findings, primary analysis separating cells by lineage revealed

296 over-representation of imprinted genes in neurons only (Table 5). The overlap between the

upregulated imprinted genes for the over-represented neural-lineage cells from both the

previous datasets are displayed in Figure 5. Additionally, PEGs alone demonstrated no

significant over-representations in global cell types while MEGs demonstrated over-

representation in vascular cells $(q=0.001)$ (Supplemental Table S5a and S5b).

Table 5. Imprinted gene over-representation in nervous system cell types (Zeisel et al. 2018). Identity Cell identities for the cells used in analysis; $U p \operatorname{Reg}$ - number of upregulated genes with $q \leq 0.05$ and $\log 2 \mathrm{FC} \geq 1$ (total 
bioRxiv preprint doi: https://doi.org/10.1101/2020.07.27.222893; this version posted October 30, 2020. The copyright holder for this preprint (which was not certified by peer review) is the author/funder, who has granted bioRxiv a license to display the preprint in perpetuity. It is made available under aCC-BY-NC-ND 4.0 International license.

number of genes in the dataset in brackets); $I G$ - number of imprinted genes upregulated with $q \leq 0.05$ and $\log 2 \mathrm{FC} \geq 1$ (total number of IGs in the dataset in brackets); ORA $p-p$ value from over representation analysis on groups with minimum $5 \%$ of total IGs; ORA $q$ - Bonferroni corrected $p$ value from ORA; Mean FC IG-mean fold change for upregulated imprinted genes; Mean FC Rest - mean fold change for all other upregulated genes; Top Cell IGs - Sum of IGs with highest mean expression value for that identity group.

\begin{tabular}{|c|c|c|c|c|c|c|c|}
\hline Identity & $\begin{array}{c}\text { Up Reg } \\
(\mathbf{1 9 , 5 5 0})\end{array}$ & $\begin{array}{c}\text { IG } \\
\mathbf{( 1 0 7 )}\end{array}$ & ORA $\boldsymbol{p}$ & ORA $\boldsymbol{q}$ & $\begin{array}{c}\text { Mean FC } \\
\text { IG }\end{array}$ & $\begin{array}{c}\text { Mean FC } \\
\text { Rest }\end{array}$ & $\begin{array}{c}\text { Top Cell } \\
\text { IGs }\end{array}$ \\
\hline Neurons & 5710 & 45 & 0.005619 & $\underline{\mathbf{0 . 0 3 3 7 1 1}}$ & 11.69 & 24.97 & \\
\hline Vascular & 2474 & 23 & 0.009964 & 0.059782 & 17.24 & 26.64 & \\
\hline Oligos & 1587 & 11 & 0.279767 & 1 & 4.13 & 11.48 & 16 \\
\hline Peripheral Glia & 2821 & 16 & 0.527651 & 1 & 5.42 & 12.64 & 12 \\
\hline Ependymal & 3684 & 20 & 0.609092 & 1 & 24.52 & 66.95 & 12 \\
\hline Immune & 1564 & 7 & 0.786456 & 1 & 13.42 & 93.05 & \\
\hline Astrocytes & 1539 & 4 & - & - & 2.88 & 10.73 & \\
\hline
\end{tabular}

Figure 5. Venn diagram of upregulated imprinted genes in the mature neuronal cells in the whole brain datasets of Zeisel et al. (2018) and Ximerakis et al. (2019). Imprinted genes are listed which show significant upregulation $(q \leq 0.05$ and $\log 2 \mathrm{FC} \geq 1)$ in the cells. Although these cell types are not identical, these were all mature neural lineage cells with over-representations in the enrichment analysis. Parental-bias is indicated by colour (MEG - red, PEG - blue. From the 119 imprinted genes in the gene list, only 88 were common to both analyses (i.e. successfully sequenced and passed gene quality control filters). 45 imprinted genes were upregulated in neurons in the MBA, and in Ximerakis et al. (2019), 33 imprinted genes were upregulated in neurons and 48 genes in neuroendocrine cells. Genes in common from the two analyses are presented in bold and totalled in each section of the Venn Diagram, while genes found upregulated in one analysis but not available in the other analysis are included in small font and

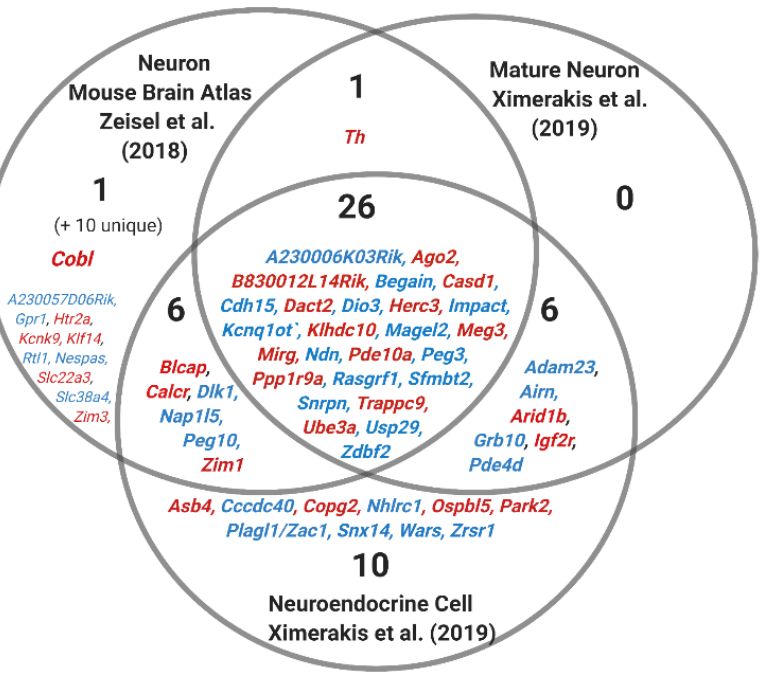
the number indicated in brackets.

301 2ii) Imprinted genes are enriched in the hypothalamus, ventral midbrain, pons, and medulla.

302 After confirming neuron-specific enrichment of imprinted genes in the MBA dataset, further

303 MBA analysis was performed on cells classified as neurons. These neuronal cells were then

304 grouped by brain/nervous system regions. Significant over-representation was seen in neurons

305 of the hypothalamus, ventral midbrain, medulla, and pons (Table 6). The pons and medulla had

306 the largest number of imprinted genes upregulated (44 for both). The imprinted gene overlap

307 for the over-represented brain regions is shown in the Venn Diagram in Figure 6a.

Table 6. Imprinted gene over-representation in nervous system regions (Zeisel et al. 2018). Identity Nervous System Regional identities for the cells used in analysis; Up Reg - number of upregulated genes with $q \leq 0.05$ and $\log 2 \mathrm{FC} \geq 1$ (total number of genes in the dataset in brackets); $I G$ - number of imprinted genes upregulated with $q$ $\leq 0.05$ and $\log 2 \mathrm{FC} \geq 1$ (total number of IGs in the dataset in brackets); ORA $p-p$ value from over representation analysis on groups with minimum 5\% of total IGs; ORA $q$ - Bonferroni corrected $p$ value from ORA; Mean FC IG mean fold change for upregulated imprinted genes; Mean FC Rest - mean fold change for all other upregulated genes; GSEA $p-p$ value from Gene Set Enrichment Analysis for identity groups with 15+ IGs and Mean FC IG > Mean FC Rest; GSEA $q$ - Bonferroni corrected $p$ values from GSEA; Top Region IGs - Sum of IGs with highest mean expression value for that identity group. 


\begin{tabular}{|c|c|c|c|c|c|c|c|c|c|}
\hline Identity & $\begin{array}{c}\text { Up Reg } \\
(18,338)\end{array}$ & $\begin{array}{l}\text { IG } \\
(\mathbf{1 0 4})\end{array}$ & ORA $p$ & ORA $q$ & $\begin{array}{c}\text { Mean } \\
\text { FC } \\
\text { IG }\end{array}$ & $\begin{array}{c}\text { Mean } \\
\text { FC } \\
\text { Rest }\end{array}$ & $\begin{array}{c}\text { GSEA } \\
p\end{array}$ & $\begin{array}{c}\text { GSEA } \\
q\end{array}$ & $\begin{array}{c}\text { Top } \\
\text { Region } \\
\text { IGs }\end{array}$ \\
\hline Medulla & 3148 & 44 & $4.28 \mathrm{E}-09$ & $6.43 \mathrm{E}-08$ & 4.79 & 4.01 & 0.0838 & 0.1676 & 15 \\
\hline Hypothalamus & 1040 & 22 & $1.17 \mathrm{E}-07$ & $\overline{1.75 \mathrm{E}-06}$ & 4.92 & 5.84 & - & - & 8 \\
\hline Pons & 3583 & 44 & $2.26 \mathrm{E}-07$ & $\underline{3.40 \mathrm{E}-06}$ & 4.15 & 3.91 & 0.0862 & 0.1724 & 22 \\
\hline Vent. Midbrain & 1229 & 18 & 0.000255 & $\underline{\underline{0.003818}}$ & 4.90 & 5.55 & - & - & 3 \\
\hline Vent. Striatum & 689 & 8 & 0.048406 & 0.726091 & 3.92 & 4.92 & - & - & 0 \\
\hline Posterior Cortex & 1090 & 9 & 0.185621 & 1 & 2.64 & 3.20 & - & - & 2 \\
\hline $\begin{array}{c}\text { Enteric Nervous } \\
\text { System }\end{array}$ & 3885 & 25 & 0.325423 & 1 & 9.07 & 121.01 & - & - & 11 \\
\hline $\begin{array}{c}\text { Sympathetic } \\
\text { Nervous System }\end{array}$ & 2805 & 18 & 0.369582 & 1 & 11.37 & 57.95 & - & - & 9 \\
\hline Anterior Cortex & 979 & 6 & 0.510693 & 1 & 2.72 & 3.30 & - & - & 1 \\
\hline Dors. Midbrain & 1045 & 6 & 0.575441 & 1 & 2.20 & 4.85 & - & - & 3 \\
\hline $\begin{array}{l}\text { Hippocampus - } \\
\text { CA1 }\end{array}$ & 1082 & 6 & 0.609895 & 1 & 3.01 & 4.02 & - & - & 2 \\
\hline Thalamus & 1441 & 8 & 0.610565 & 1 & 2.90 & 6.36 & - & - & 0 \\
\hline Dors. Striatum & 1196 & 6 & 0.705864 & 1 & 4.03 & 5.43 & - & - & 2 \\
\hline $\begin{array}{l}\text { Somatosensory } \\
\text { Cortex }\end{array}$ & 2121 & 11 & 0.705992 & 1 & 4.09 & 3.70 & - & - & 8 \\
\hline $\begin{array}{l}\text { Dorsal Root } \\
\text { Ganglion }\end{array}$ & 3607 & 15 & 0.949802 & 1 & 11.55 & 75.87 & - & - & 8 \\
\hline Amygdala & 452 & 4 & - & - & 4.65 & 4.11 & - & - & 2 \\
\hline Cerebellum & 240 & 0 & - & - & 0.00 & 32.30 & - & - & 0 \\
\hline $\begin{array}{l}\text { Antero-Central } \\
\text { Cortex }\end{array}$ & 646 & 3 & - & - & 4.59 & 4.31 & - & - & 1 \\
\hline Middle Cortex & 623 & 5 & - & - & 3.29 & 3.24 & - & - & 0 \\
\hline Dentate Gyrus & 796 & 4 & - & - & 3.79 & 4.16 & - & - & 2 \\
\hline Hippocampus & 631 & 4 & - & - & 4.86 & 3.82 & - & - & 2 \\
\hline Olfactory Bulb & 445 & 4 & - & - & 4.02 & 8.27 & - & - & 2 \\
\hline
\end{tabular}

308 Regional analysis for MEGs and PEGs separately (Supplemental Table S6a and S6b),

309 revealed that PEGs were over-represented in hypothalamus $\left(q=1.21 \times 10^{-7}\right)$, ventral midbrain

$310(q=0.023)$, the pons $(q=0.001)$ and the medulla $(q=0.0001)$; while MEGs were only over-

311 represented in the medulla $(q=0.002)$ and pons $(q=0.011)$ with a significant GSEA for the

312 pons $(q=0.028$, Appendix B3); see Figure 6b.

313 We then recategorized the neurons into individual neuronal subtypes to uncover the specific

314 neural population underlying the enrichment seen in the hypothalamus, pons and medulla,

315 and midbrain (Figure 7; Supplemental Table S7). The hypothalamus was represented by a

316 selection of inhibitory and peptedergic neurons. Inhibitory neurons with over-representation

317 of imprinted genes included: Deinh4 (Syt2, Smim17) representing a Subthalamic Nucleus

318 population, Deinh5 (Nts, Gal Esrl, Prlr) representing a Preoptic Area population, Deinh6

319 (Agrp, Npy) representing an Arcuate nucleus population, and Deinh7 (Avp, Rgs16) and

320 Deinh8 (Nms, Vip) suspected to be Suprachiasmatic nucleus populations. For peptedergic 
bioRxiv preprint doi: https://doi.org/10.1101/2020.07.27.222893; this version posted October 30, 2020. The copyright holder for this preprint (which was not certified by peer review) is the author/funder, who has granted bioRxiv a license to display the preprint in perpetuity. It is made available under aCC-BY-NC-ND 4.0 International license.

neurons, over-representation was seen in HYPEP3 (Gpr101, Tac1) a ventromedial

magnocellular population of the paraventricular and supraoptic nuclei, and HYPEP6 (Hcrt,

$325 \mathrm{Tr} h r$ ) an orexin producing population of the dorsomedial/lateral hypothalamus.

326 The midbrain, medulla and pons were represented by a number of cell groups. Of interest, overrepresentation was seen in the medulla-based adrenergic (HBAR) and noradrenergic (HBNOR)

inhibitory (MEINH, HBIN) and excitatory neuron (MEGLU, HBGLU) types spread across the

3303 regions in nuclei (Figure 6). The serotonergic populations of the raphe nuclei of these regions

Figure 6. Level 2ii) brain region analysis summary figures

6a) Venn diagram of upregulated imprinted genes in the neurons of over-represented nervous system regions from the Mouse Brain Atlas (Zeisel et al. 2018). Imprinted genes are listed which show significant upregulation $(q \leq$ 0.05 and $\log 2 \mathrm{FC} \geq 1$ ) in the regions specified. The number of imprinted genes in each region of the Venn diagram are

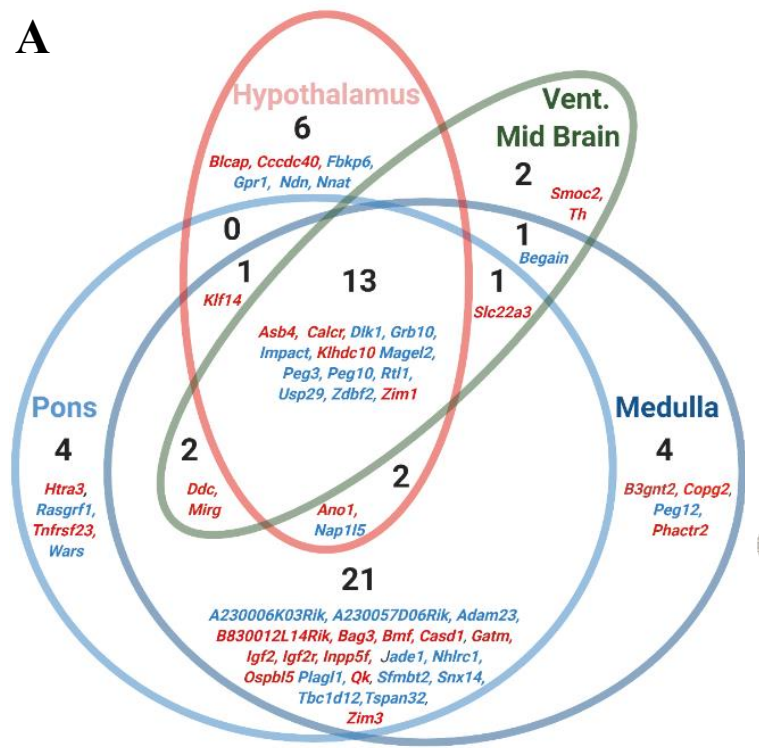
specified. Parental-bias of imprinted genes is indicated by colour (MEG - red, PEG - blue).

6b) Imprinted gene over-represented brain regions in the MBA (Zeisel et al. 2018). Regions over-represented for all imprinted genes are bolded. Regions overrepresented for PEGs alone are coloured blue while regions over-represented for MEGS alone are coloured red.

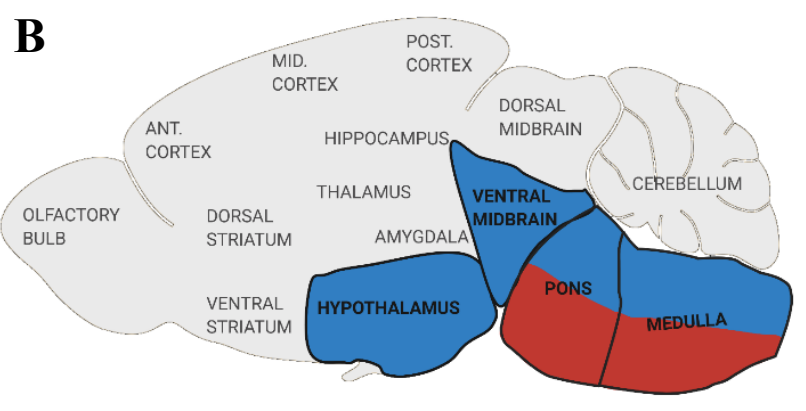

331 (HBSER) are particularly prominent since the pons and medulla base serotonin neuron

332 populations (HBSER2, HBSER4 and HBSER5) were the only neuron subpopulations out of

333 the 214 total to have a significant GSEA for imprinted genes after correction (Appendix B4).

334 Additional regions of over-representation included TEINH1-3 representing neurons in the

335 pallidum and striatum and DEINH4 representing PVN neurons from the thalamus. In this 
bioRxiv preprint doi: $h$ ttps://doi.org/10.1101/2020.07.27.222893; this version posted October 30, 2020. The copyright holder for this preprint (which was not certified by peer review) is the author/funder, who has granted bioRxiv a license to display the preprint in perpetuity. It is made available under aCC-BY-NC-ND 4.0 International license.

comparison of 214 neuron populations, no neurons from areas such as the cortex, cerebellum

338 previous regional analysis. Hence, further analysis focused on those brain regions enriched in

339 this cross-brain level analysis.

\section{3) Brain Region level Analysis}

341 We next sought to identify enriched neuronal subpopulations within the brain regions

Figure 7. Anatomical labelling of all the neural subpopulations with a significant over-representation of imprinted genes $(q \leq 0.05$ and $\log 2 \mathrm{FC} \geq 1)$ in the Mouse Brain Atlas (Zeisel et al. 2018). The predicted brain nuclei localisation of the 32 neuronal subpopulations (out of 214 populations identified across the nervous system) specified in the MBA and enriched for imprinted genes. Brain regions that were not found to be enriched for imprinted genes are greyed out. The full Enrichment Analysis is available in Supplementary Table 6.

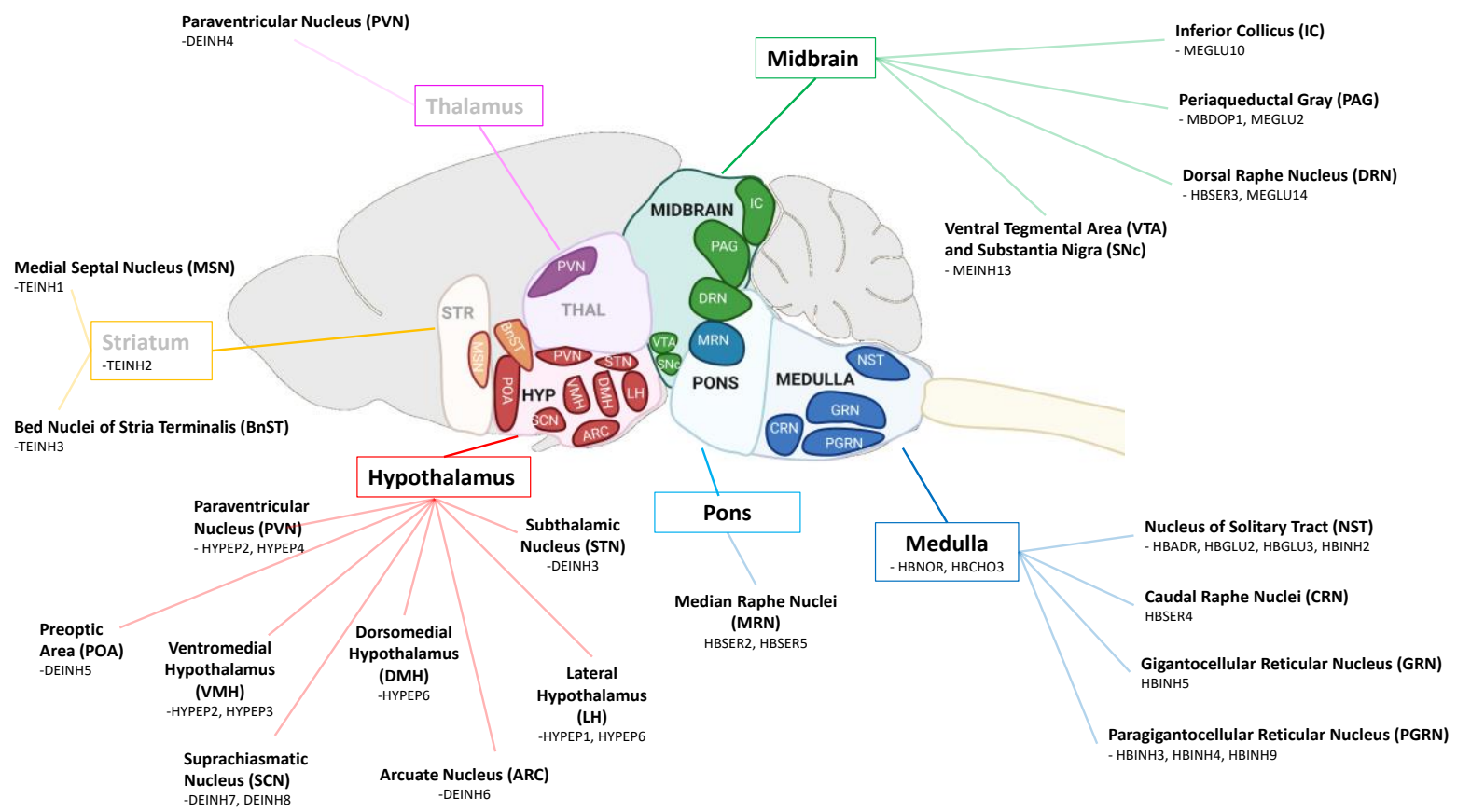

342 identified above. Namely within the hypothalamus (to identify populations enriched across

343 the whole hypothalamus and those enriched within specific hypothalamic nuclei) and whether

344 imprinted genes were enriched in the dopaminergic and serotonergic populations spread

345 across the ventral midbrain and hindbrain and key subpopulations in the whole brain analysis

\section{3a) Whole Hypothalamus}

347 3ai) Imprinted genes are over-represented in hypothalamic neurons

348 Two datasets with single cell sequencing data for the adult hypothalamus exist (Chen et al. 
bioRxiv preprint doi: https://doi.org/10.1101/2020.07.27.222893; this version posted October 30, 2020. The copyright holder for this preprint (which was not certified by peer review) is the author/funder, who has granted bioRxiv a license to display the preprint in perpetuity. It is made available under aCC-BY-NC-ND 4.0 International license.

350 allowing us to look for convergent imprinted enrichment across major hypothalamic neuronal

351 subtypes. Analysis revealed a clear neuronal bias in expression for imprinted genes

352 (Supplemental Table S8a and S9a). Within the Romanov et al. (2017) data, there was a

353 significant over-representation of imprinted genes in neurons $(q=0.02)$ and a similar

354 observation was seen in the Chen et al. (2017) data $(q=0.001)$, and both also demonstrated a

355 significant GSEA in neurons (Figure 8a-d, Romanov et al. $2017-p=0.012$, Chen et al. 2017

$356-p=0.019)$.

3aii) Imprinted genes are over-represented in specific hypothalamic neuronal sub-types

358 Within the Chen et al. (2017) dataset, 4/33 hypothalamic neuronal subtypes had a significant over-representation of imprinted genes (Table 7a; Supplemental table S8b). The four subtypes

360 were all GABAergic neurons, specifically: GABA13 (Slc18a2, Gal), with high expression of

361 Gal, Esrl, Prlr and Th, present in a few hypothalamic regions (but concentrated in the POA);

362 GABA17 (Slc6a3) a dopaminergic neuron type with high expression of Th and Prlr, which

363 most likely corresponds to the TIDA neurons of the arcuate nucleus; GABA8 (Vipr2) with very

364 high Avp and Nms expression suggesting these are neurons from the SCN; and GABA15 (Agrp)

365 feeding promoting neurons of the Arcuate Nucleus. Within the Romanov et al. (2017) dataset,

366 3/62 subtypes had significant over-representation of imprinted genes (Table 7b; Supplemental

367 table S9b): GABA5 (Calcr, $L h x l$ ) whose largest upregulated gene is Slc6a3 and which likely

Table 7a-b. Imprinted gene over-representation in Whole Hypothalamic Datasets: 7a. Chen et al. (2017) and 7b. Romanov et al. (2017). Identity - Neuronal Subpopulations for the cells used in analysis; Up Reg - number of upregulated genes number of upregulated genes with $q \leq 0.05$ and positive Log2FC (total number of genes in the dataset in brackets); $I G$ - number of imprinted genes upregulated with $q \leq 0.05$ and positive Log2FC (total number of IGs in the dataset in brackets); ORA $p-p$ value from over representation analysis on groups with minimum $5 \%$ of total IGs; ORA $q$ - Bonferroni corrected $p$ value from ORA; Mean FC IG - mean fold change for upregulated imprinted genes; Mean FC Rest - mean fold change for all other upregulated genes

\begin{tabular}{|c|c|c|c|c|c|c|}
\hline Identity & Up Reg & IG & ORA $p$ & ORA $q$ & Mean FC IG & Mean FC Rest \\
\hline 7a) Whole Hypothalamus & $(12,167)$ & (79) & \multicolumn{4}{|c|}{ Chen et al. (33 neuron types) } \\
\hline GABA17 (Slc6a3) & 823 & 18 & $3.96 \mathrm{E}-06$ & 9.50E-05 & 2.73 & 3.28 \\
\hline GABA8 (Vipr2) & 478 & 11 & 0.000247 & $\underline{0.005935}$ & 1.96 & 2.72 \\
\hline GABA13 (Slc18a2, Gal) & 568 & 12 & 0.000279 & $\overline{0.006687}$ & 1.89 & 2.01 \\
\hline GABA15 (Agrp) & 764 & 13 & 0.001190 & $\overline{0.028553}$ & 2.40 & 2.78 \\
\hline 7b) Whole Hypothalamus & $(12,812)$ & (86) & \multicolumn{4}{|c|}{ Romanov et al. (62 neuron types) } \\
\hline GABA 5 (Calcr, Lhx1) & 41 & 6 & $2.86 \mathrm{E}-07$ & $2.00 \overline{E-06}$ & 3.47 & 5.10 \\
\hline GABA 14 (Npy, Agrp) & 193 & 6 & 0.0018726 & $\overline{0.013108}$ & 2.94 & 6.12 \\
\hline Ghrh & 235 & 6 & 0.004954 & 0.034677 & 18.31 & 17.19 \\
\hline
\end{tabular}


bioRxiv preprint doi: https://doi.org/10.1101/2020.07.27.222893; this version posted October 30, 2020. The copyright holder for this preprint (which was not certified by peer review) is the author/funder, who has granted bioRxiv a license to display the preprint in perpetuity. It is made available under aCC-BY-NC-ND 4.0 International license.

Arcuate Nucleus feeding neurons also reported in Chen et al. (2017); and a Ghrh neuronal type,

also strongly upregulated for Th, which was not over-represented in Chen et al. (2017).

Figure 8. Imprinted gene GSEA for genes upregulated in neurons across the whole hypothalamus.

8a) Chen et al. 2017 - GSEA graph - In the analysis, genes are sorted by strength by which they mark this neuronal cluster (sorted by Log2FC values) indicated by the bar (bottom). The genes are arrayed left (strongest marker) to right and blue lines mark where imprinted genes fall on this array. The vertical axis indicates an accumulating weight, progressing from left to right and increasing or decreasing depending on whether the next gene is an imprinted gene or not. The $p$-value represents the probability of observing the maximum value of the score (red dashed line) if the imprinted genes are distributed randomly along the horizontal axis. Abbr: OPC = Oligodendrocyte Precursor Cell, MG = Myelinating Oligodendrocyte, IMG = Immature Oligodendrocyte, Astro = Astrocyte, Epith = Epithelial, Macro = Macrophage, Tany $=$ Tanycyte, Ependy = Ependymocyte, Micro = Microglia, POPC = Proliferating Oligodendrocyte Progenitor Cell.

8b) Chen et al. 2017 - Dot Plot - Upregulated imprinted genes in neurons, separated by MEGs and PEGs, were plotted across all cell types in Ximerakis et al. 2019. Size of points represented absolute mean expression; colour represented the size of the $\log 2 \mathrm{FC}$ value for neurons vs. all other cells across the hypothalamus.

8c) Romanov et al. 2017 - GSEA Graph See 7a description for details.

8d) Romanov et al. 2017 - Dot Plot See $7 \mathrm{~b}$ description for details.

A

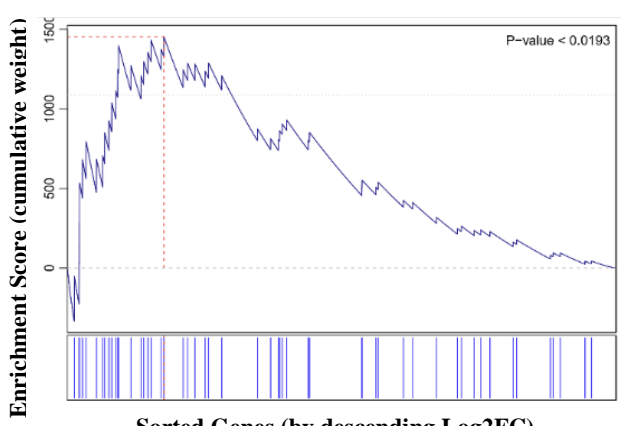

B

Sorted Genes (by descending $\log 2 \mathrm{FC}$ )

C

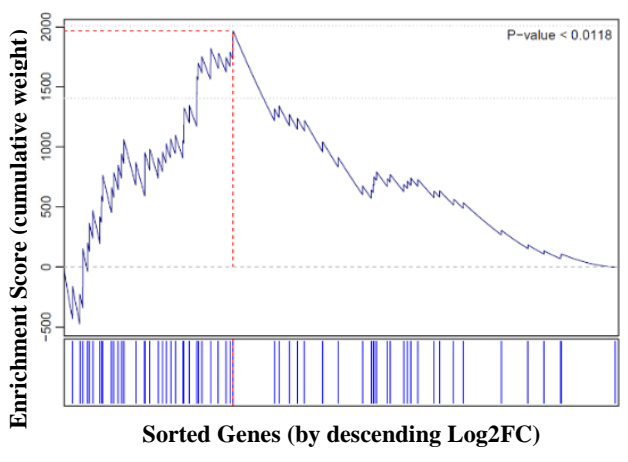

PEGs MEGs
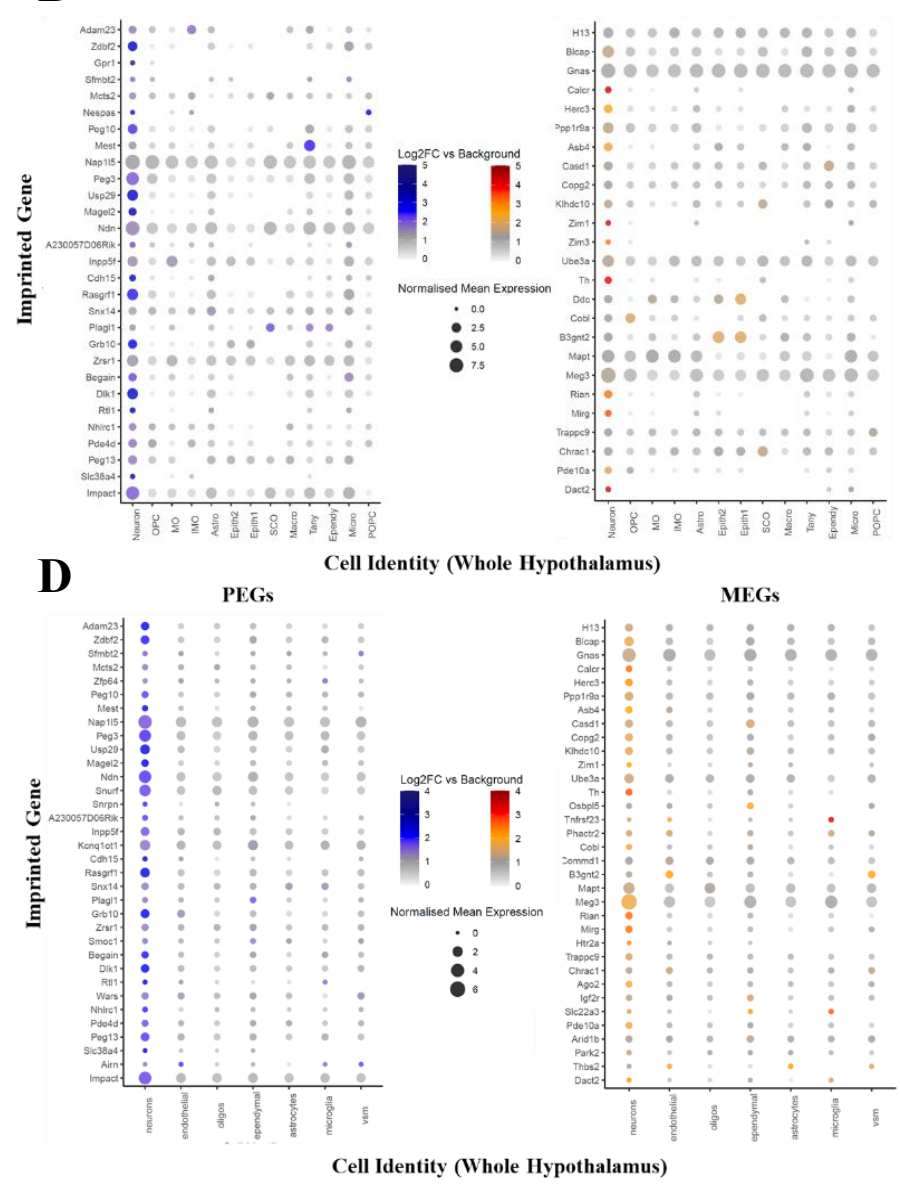
375 Arcuate Nucleus - ARC (Campbell et al. 2017)

376 The first nuclei investigated was the Arcuate Nucleus sequenced by Campbell et al. (2017).

377 Imprinted gene over-representation was found in 8/24 arcuate neuron types (Table 8a;

378 Supplemental Table S10). These included the major Agrp/Npy neuron type (Agrp/Sst) and both

379 major Pomc neuron types known to be feeding suppressants (Rau and Hentges 2017).

380 Additional significant over-representation was found in the Ghrh neuron type, which was also

381 enriched in Galanin and Th. Finally, a highly significant over-representation of IGs was found

382 in the Th/Slc6a3 neuron type identified by the authors as one of the most likely candidates for

383 the TIDA dopaminergic neuron population. Marker genes for this identity group overlapped

384 with the TIDA candidates from the previous two datasets (e.g. Slc6a3, Th, Lhx1, Calcr). Agrp

385 neurons and these TIDA candidate neurons were identified in both whole hypothalamic

386 datasets and at the nuclei level.

$387 \quad$ Preoptic Area - POA (Moffitt et al. 2018)

388 Imprinted gene over-representation was found in $14 / 66$ of the neuron clusters identified by

389 Moffitt et al. (2018) in the preoptic area (Supplemental Table S11a). Moffitt et al. (2018) stated

390 that 9 of the 66 clusters most likely originate from outside the POA including 3/14 of the

391 imprinted gene enriched neuron clusters (one of which was the Avp/Nms neurons $(q=0.0003)$

392 likely to be from the SCN). To focus our analysis on the POA alone, we removed the non-POA

393 neuron groups and ran the analysis on the remaining neural groups restricted to POA (Table

394 8b; Supplemental Table S11b). Imprinted genes were found to be over-represented in 15

395 neuron types including two Galanin enriched clusters (i22, i8), the major Th enriched cluster

396 (i17), e15:Ucn3/Brs3 (a cluster activated by parenting), a Crh cluster (i35) and a Trh cluster

397 (e4), and both major glutamatergic Ghrh clusters (e13, e19). Since a considerable number of

398 neuron types were over-represented, the above analysis was run again with the $\log 2 \mathrm{FC} \geq 1$

399 criteria to find out if imprinted genes were enriched in the more distinct markers (Supplemental 
400 Table S11c). Only two neuron types were over-represented: i35:Crh/Tac2 $(q=0.0126)$ and

401 i16:Gal/Th $(q=0.0026)$. i16:Gal/Th is a prominent behavioural neuron group (parenting and

402 mating behaviour) which was not identified in the previous analysis. Only three of Moffitt et

403 al.'s (2018) neuron groups were upregulated in Slc18a2, Gal, Prlr, Th and Esr1 (i8, i16, i38)

404 like GABA13 in Chen et al. (2017) and all of them are represented above.

405 Lateral Hypothalamic Area- LHA (Mickelsen et al. 2019)

406 Over-representation of imprinted genes in the Lateral Hypothalamic Area neurons was

407 analysed for Glutamatergic and GABAergic neurons separately since they were sequenced

408 separately by Mickelsen et al. (2019). For Glutamatergic neurons, imprinted gene over-

409 representation was found in 6/15 clusters (Table 8ci, Supplemental Table S12a). These

410 included: Glut 6 (Hcrt) identified as the Orexin cluster, a classic motivated behaviour neuronal

411 subset identified in the MBA as HYPEP6; and Glut 9 (Synpr/Gad1) with a significant GSEA

412 (Appendix B5) and synaptoporin as a marker gene an; it is a cell type scattered across the LHA

413 and DMH. The four others were Glut 14 (Otp/Gpr101), Glut 7 (Gpr101/Tcf4), Glut 5

414 (Ebf3/Otp) and Glut 11 (Calca/Col27al) which were all enriched in similar genes such as Otp,

$415 T c f 4$ and Gpr101. The authors did not describe a clear functional role associated with these

416 neurons, but their gene expression (namely Gpr101 and Otp) likens these neurons to HYPEP1

417 and HYPEP3 from the MBA. For GABAergic neurons imprinted gene over-representation was

418 found in 2/15 clusters: Gaba 1 (Gal/Dlk1), a galanin enriched cluster, previously shown to

419 modulate food reward (Qualls-Creekmore et al. 2017) and Gaba 5 (Meis2/Calb2), a sub-type

420 also lacking functional classification (Table 8cii; Supplemental Table S12b).

421 Suprachiasmatic Nucleus - SCN (Wen et al. 2020)

422 Analysis of the 10x chromium data of only SCN neurons (Table 8d, Supplemental Table S13)

423 revealed a significant over-representation and GSEA (Appendix B6) in the Avp/Nms neuronal

424 cluster only. This cluster shows the strongest expression for Oxt, Avp, Avprla and Prlr and is 
bioRxiv preprint doi: https://doi.org/10.1101/2020.07.27.222893; this version posted October 30, 2020. The copyright holder for this preprint (which was not certified by peer review) is the author/funder, who has granted bioRxiv a license to display the preprint in perpetuity. It is made available under aCC-BY-NC-ND 4.0 International license.

one of the three neural group that Wen et al. (2020) found had robust circadian gene expression,

426 and the only subtype with notable phase differences in circadian gene expression in the dorsal

427 SCN). This cluster likely corresponds to the GABA8 cluster found enriched in the Chen et al.

428 (2017) dataset and the Avp/Nms group identified by Moffitt et al. (2018) as an off-target

429 neuronal group.

Table 8a-d. Imprinted gene over-representation in individual hypothalamic datasets: 8a. Arcuate Nucleus (ARC) - Campbell et al. (2017), 8b. Preoptic Area (POA) - Moffitt et al. (2018), 8c. Lateral Hypothalamic Area (LHA) - Mickelsen et al. (2019) and, 8d. Suprachiasmatic Nucleus (SCN) - Wen et al. (2020). Identity - Nervous System Regional identities for the cells used in analysis, total number of neuronal types in brackets; Up Reg - number of upregulated genes with $q \leq 0.05$ and positive Log2FC (total number of genes in the dataset in brackets); $I G$ - number of imprinted genes upregulated with $q \leq 0.05$ and positive Log2FC (total number of IGs in the dataset in brackets); ORA $p-p$ value from over representation analysis on groups with minimum 5\% of total IGs; ORA $q$ - Bonferroni corrected $p$ value from ORA; Mean FC IG - mean fold change for upregulated imprinted genes; Mean FC Rest - mean fold change for all other upregulated genes; GSEA $p-p$ value from Gene Set Enrichment Analysis for identity groups with 15+ IGs and Mean FC IG > Mean FC Rest; GSEA $q$ - Bonferroni corrected $p$ values from GSEA

\begin{tabular}{|c|c|c|c|c|c|c|c|c|}
\hline Identity & Up Reg & IG & ORA $p$ & ORA $q$ & $\begin{array}{l}\text { Mean } \\
\text { FC IG }\end{array}$ & $\begin{array}{c}\text { Mean FC } \\
\text { Rest }\end{array}$ & $\begin{array}{c}\text { GSEA } \\
p\end{array}$ & GSEA $q$ \\
\hline a) $\mathrm{ARC}$ & $(16,098)$ & (94) & \multicolumn{6}{|c|}{ (24 neuron types) } \\
\hline Th/Slc6a3 & 1113 & 26 & 7.49E-10 & $\underline{1.72 \mathrm{E}-08}$ & 2.14 & 4.04 & - & - \\
\hline Arx/Nr5a2 & 599 & 16 & $3.98 \mathrm{E}-07$ & $9.16 \mathrm{E}-06$ & 1.33 & 3.15 & - & - \\
\hline Agrp/Sst & 1704 & 23 & 0.000111 & $\underline{0.002552}$ & 1.61 & 1.78 & - & - \\
\hline Pomc/Anxa2 & 3162 & 34 & 0.000168 & $\overline{\mathbf{0 . 0 0 3 8 6 6}}$ & 1.70 & 1.82 & - & - \\
\hline Ghrh & 1265 & 18 & 0.000382 & $\underline{\underline{0.008793}}$ & 2.02 & 2.82 & - & - \\
\hline Gpr50 & 578 & 11 & 0.000591 & $\overline{0.013595}$ & 2.52 & 5.02 & - & - \\
\hline Pomc/Glipr1 & 1536 & 19 & 0.001426 & $\underline{0.032792}$ & 1.91 & 1.90 & 0.2851 & 0.8553 \\
\hline Slc17a6/Trhr & 1547 & 19 & 0.001550 & $\overline{0.035651}$ & 3.22 & 2.35 & 0.1143 & 0.3429 \\
\hline b) POA & $(16,402)$ & (100) & \multicolumn{6}{|c|}{ (57 neuron types) } \\
\hline i22:Gal/Pmaip1 & 1569 & 27 & 4.64E-07 & $\underline{2.41 E-05}$ & 2.02 & 2.14 & - & - \\
\hline i8:Gal/Amigo2 & 3625 & 42 & $6.29 \mathrm{E}-06$ & 0.000327 & 1.78 & 1.53 & 0.1628 & 1 \\
\hline e15:Ucn3/Brs3 & 996 & 18 & $2.90 \mathrm{E}-05$ & $\underline{0.001510}$ & 6.15 & 3.43 & 0.04 & 0.32 \\
\hline i12:Gaba & 1229 & 20 & $4.40 \mathrm{E}-05$ & $\overline{0.002286}$ & 1.76 & 1.68 & 0.2236 & 1 \\
\hline i35:Crh/Tac2 & 1464 & 22 & 5.69E-05 & $\underline{0.002961}$ & 1.98 & 2.44 & - & - \\
\hline i17:Th/NosI & 1358 & 21 & $5.76 \mathrm{E}-05$ & $\overline{0.002998}$ & 2.02 & 2.00 & 0.4519 & 1 \\
\hline e4:Trh/Angpt1 & 2770 & 33 & $6.13 \mathrm{E}-05$ & $\overline{0.003188}$ & 1.90 & 2.28 & - & - \\
\hline e19:Ghrh/Trh & 1974 & 26 & $9.75 \mathrm{E}-05$ & $\underline{0.005068}$ & 2.14 & 3.88 & - & - \\
\hline e1:Glut & 1518 & 22 & $9.76 \mathrm{E}-05$ & $\underline{0.005073}$ & 1.58 & 1.87 & - & - \\
\hline e12:Nos1/Foxp2 & 1635 & 22 & 0.000284 & $\overline{\mathbf{0 . 0 1 4 7 9 0}}$ & 1.81 & 2.64 & - & - \\
\hline i1:Gaba & 602 & 12 & 0.000295 & $\underline{0.015355}$ & 1.20 & 1.55 & - & - \\
\hline i24:Nmu & 3020 & 33 & 0.000334 & $\underline{0.017349}$ & 1.71 & 2.02 & - & - \\
\hline e13:Ghrh/C1ql1 & 3588 & 37 & 0.000398 & $\overline{0.020691}$ & 2.58 & 2.81 & - & - \\
\hline i37:Bdnf/Chrm2 & 2078 & 25 & 0.000561 & $\overline{\mathbf{0 . 0 2 9 1 6 8}}$ & 2.80 & 3.17 & - & - \\
\hline i38:Kiss1/Th & 2078 & 25 & 0.000561 & $\underline{0.029168}$ & 2.09 & 5.11 & - & - \\
\hline ci) LHA GLUT & $(11,909)$ & (78) & \multicolumn{6}{|c|}{ (15 neuron types) } \\
\hline Glut_11 (Calca, Col27a1) & 392 & 13 & $1.86 \mathrm{E}-06$ & $\underline{2.61 E-05}$ & 1.89 & 3.47 & - & - \\
\hline Glut_7 (Gpr101, Tcf4) & 253 & 10 & 7.00E-06 & $\overline{9.80 \mathrm{E}-05}$ & 1.55 & 2.59 & - & - \\
\hline Glut_14 (Otp/Gpr101) & 369 & 11 & $3.36 \mathrm{E}-05$ & $\overline{\mathbf{0 . 0 0 0 4 7 0}}$ & 1.38 & 2.08 & - & - \\
\hline Glut_9 (Synpr/Gad1) & 784 & 15 & 0.000196 & $\underline{0.002743}$ & 2.17 & 2.02 & 0.0099 & $\underline{0.0198}$ \\
\hline Glut_5 (Ebf3/Otp) & 720 & 14 & 0.000280 & $\underline{0.003915}$ & 1.74 & 1.64 & - & - \\
\hline Glut_6 (Hcrt) & 3097 & 35 & 0.000423 & $\overline{0.005924}$ & 3.15 & 2.29 & 0.1385 & 0.277 \\
\hline cii) LHA GABA & $(11,572)$ & (75) & \multicolumn{6}{|c|}{ (15 neuron types) } \\
\hline Gaba_1 (Gal, Dlk1) & 1021 & 19 & $2.82 \mathrm{E}-05$ & $\underline{0.000395}$ & 1.62 & 1.50 & 0.0601 & 0.1202 \\
\hline Gaba_5 (Meis2, Calb2) & 646 & 12 & 0.001076 & $\overline{0.015062}$ & 1.26 & 1.82 & - & - \\
\hline d) $\mathrm{SCN}$ & $(11,391)$ & (77) & \multicolumn{6}{|c|}{ (5 neuron types) } \\
\hline Avp/Nms & 909 & 24 & 3.01E-09 & $\underline{1.51 \mathrm{E}-08}$ & 3.12 & 1.94 & $\underline{0.004}$ & - \\
\hline
\end{tabular}


bioRxiv preprint doi: https://doi.org/10.1101/2020.07.27.222893; this version posted October 30, 2020. The copyright holder for this preprint (which was not certified by peer review) is the author/funder, who has granted bioRxiv a license to display the preprint in perpetuity. It is made available under aCC-BY-NC-ND 4.0 International license.

430 Figure 9 presents the overlapping upregulated imprinted genes from the convergently

431 upregulated neuron subtypes in the hypothalamic analysis of level 3a and $3 \mathrm{~b}$.

Figure 9. Venn diagrams of upregulated imprinted genes in the neuronal subpopulations from level $\mathbf{3 b}$ that were also identified in level 3a. Imprinted gene overlap was contrasted from Th/Slc6a3, Ghrh and Agrp/Sst neuronal populations of the Arcuate Nucleus (Campbell et al. 2017), Avp/Nms neurons from the Suprachiasmatic Nucleus (Wen et al. 2020) and i16 (Gal/Th) neurons from the Preoptic Area (Moffitt et al. 2018). These populations were represented at level $3 \mathrm{a}$ and level $3 \mathrm{~b}$ analyses. Imprinted genes are listed which show significant upregulation $(q \leq 0.05$ and $\log 2 \mathrm{FC}>0$ ) in the subpopulation. Parental-bias is indicated by colour (MEG - red, PEG - blue).

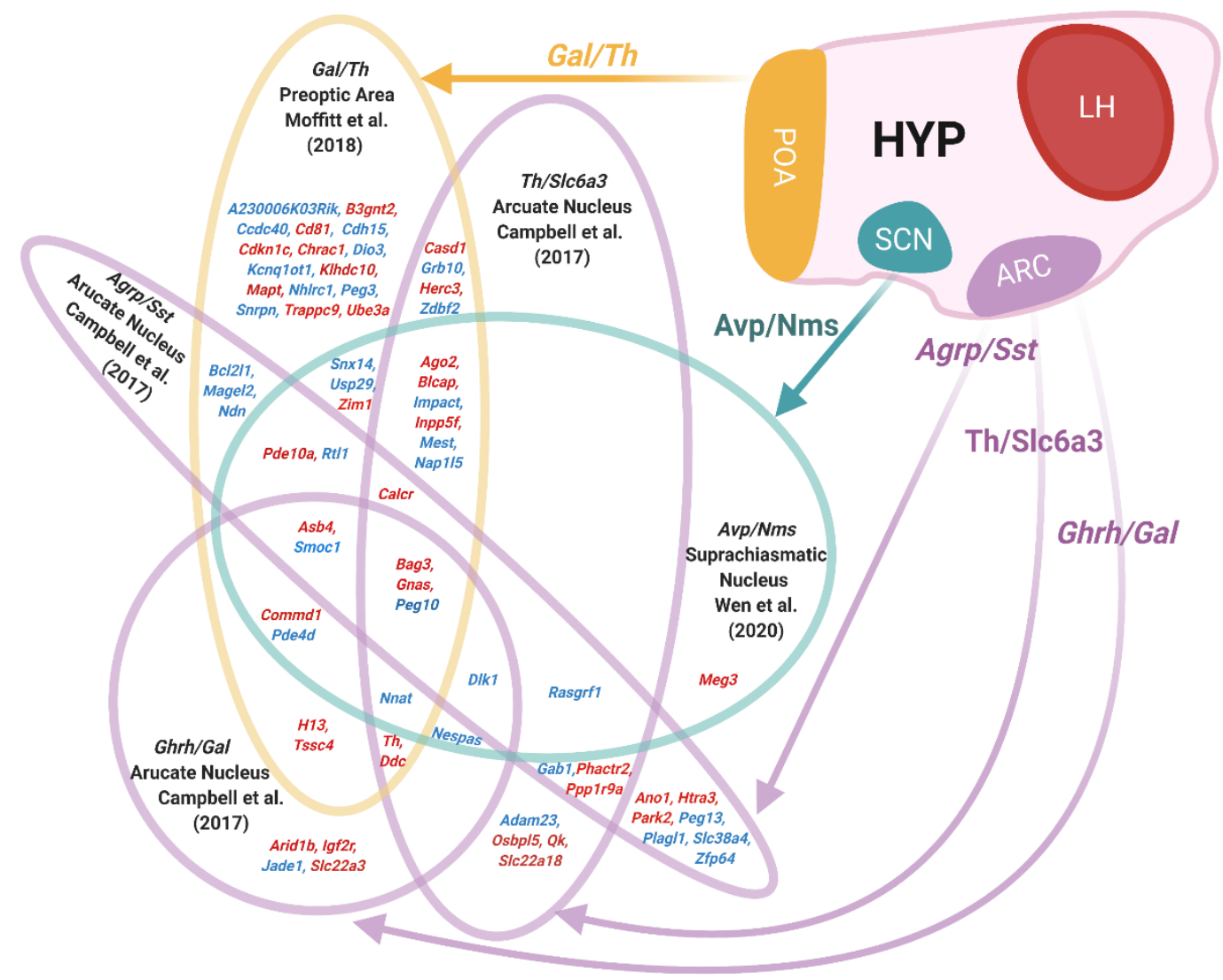

3c) Monoaminergic Nuclei

433 3ci) Imprinted genes are over-represented in $T h+v e$ mature dopaminergic neurons

434 In the MBA, Whole Hypothalamus and Arcuate Nucleus analyses, dopaminergic clusters were

435 consistently enriched and, to further explore dopaminergic enrichment, analysis of Hook et al.'s

436 (2018) data allowed comparison for dopamine neurons across the brain (olfactory bulb, arcuate

437 nucleus and midbrain) at two developmental timepoints (E15.5 and Post-natal day (P) 7). The

438 arcuate nucleus P7 dopamine neurons emerged as the clearest over-represented subgroups

439 (Table 9). This included the Th/Slc6a3 neurons and the Gal/Ghrh cluster considered

440 'neuroendocrine' cells by Hook et al. (2018). Additionally, P7 midbrain neurons were the other 
bioRxiv preprint doi: https://doi.org/10.1101/2020.07.27.222893; this version posted October 30, 2020. The copyright holder for this preprint (which was not certified by peer review) is the author/funder, who has granted bioRxiv a license to display the preprint in perpetuity. It is made available under aCC-BY-NC-ND 4.0 International license.

441 group with significant over-representation (PAG and VTA) as well as the neuroblasts at this

442 time point.

Table 9. Imprinted gene over-representation in brain-wide dopaminergic neurons (Hook et al. 2018). Identity - Cell identities for the cells used in analysis; Up Reg - number of upregulated genes with $q \leq 0.05$ and positive Log2FC (total number of genes in the dataset in brackets); $I G$ - number of imprinted genes upregulated with $q \leq 0.05$ and positive $\log 2 \mathrm{FC}$ (total number of IGs in the dataset in brackets); ORA $p$ $-p$ value from over representation analysis on groups with minimum 5\% of total IGs; ORA $q$ - Bonferroni corrected $p$ value from ORA; Mean FC IG - mean fold change for upregulated imprinted genes; Mean FC Rest - mean fold change for all other upregulated genes

\begin{tabular}{|c|c|c|c|c|c|c|}
\hline Identity & $\begin{array}{c}\text { Up Reg } \\
(\mathbf{1 3 , 0 9 5})\end{array}$ & $\begin{array}{c}\text { IG } \\
(\mathbf{8 6})\end{array}$ & ORA $\boldsymbol{p}$ & ORA $\boldsymbol{q}$ & $\begin{array}{c}\text { Mean FC } \\
\text { IG }\end{array}$ & $\begin{array}{c}\text { Mean FC } \\
\text { Rest }\end{array}$ \\
\hline Arcuate Nucleus (Th, Slc6a3, Prlr) (P7) & 912 & 26 & $9.90 \mathrm{E}-11$ & $\mathbf{1 . 0 9 E - 0 9}$ & 2.10 & 2.10 \\
\hline Arcuate Nucleus (Th, Ghrh, Gal) $\mathbf{( P 7 )}$ & 552 & 14 & $1.50 \mathrm{E}-05$ & $\underline{\mathbf{0 . 0 0 0 1 6 5}}$ & 3.34 & 4.05 \\
\hline Periaqueductal Gray (P7) & 656 & 14 & $9.90 \mathrm{E}-05$ & $\underline{\mathbf{0 . 0 0 1 0 8 9}}$ & 2.95 & 4.48 \\
\hline Midbrain Neuroblast (P7) & 1092 & 18 & 0.000251 & $\underline{\mathbf{0 . 0 0 2 7 5 7}}$ & 2.36 & 2.81 \\
\hline Ventral Tegmental Area (P7) & 1855 & 24 & 0.000775 & $\underline{\mathbf{0 . 0 0 8 5 2 6}}$ & 2.01 & 2.41 \\
\hline Substantia Nigra (P7) & 2532 & 21 & 0.157969 & 1 & 2.37 & 2.59 \\
\hline Olfactory Bulb Mature Th+(P7) & 678 & 7 & 0.163674 & 1 & 3.93 & 4.33 \\
\hline Post-mitotic midbrain neuron (E15.5) & 1362 & 11 & 0.292853 & 1 & 3.41 & 2.32 \\
\hline Forebrain neuroblast (E15.5) & 3207 & 20 & 0.668062 & 1 & 1.92 & 1.97 \\
\hline Midbrain Neuroblast (E15.5) & 5117 & 29 & 0.888038 & 1 & 1.94 & 2.63 \\
\hline Post-mitotic forebrain Th+ (E15.5) & 1174 & 5 & 0.900062 & 1 & 2.05 & 2.76 \\
\hline Olfactory Bulb maturing Th+(P7) & 350 & 4 & - & - & 4.47 & 5.35 \\
\hline Olfactory Bulb immature Th+(P7) & 127 & 2 & - & - & 3.74 & 5.46 \\
\hline
\end{tabular}

443 Although no detailed adult mouse midbrain datasets exist, La Manno et al.'s (2016) ventral

444 midbrain sequencing at E11.5 - E18.5 allowed us to identify imprinted enrichment within the

445 midbrain at a timepoint when the major neuronal populations are differentiating but still

446 identifiable (Table 10). As anticipated, we found significant over-representation in

447 dopaminergic neurons, both mature (DA1; high Th and Slc6a3) and developing (DA0) as well

448 as the serotonergic neurons likely from the midbrain raphe nuclei.

Table 10. Imprinted gene over-representation in developing midbrain cell types (La Manno et al. 2016). Identity - Nervous System Regional identities for the cells used in analysis; $U p$ Reg - number of upregulated genes with $q$ $\leq 0.05$ and positive Log2FC (total number of genes in the dataset in brackets); $I G$-number of imprinted genes upregulated with $q \leq 0.05$ and positive Log2FC (total number of IGs in the dataset in brackets); ORA $p-p$ value from over representation analysis on groups with minimum 5\% of total IGs; ORA $q$ - Bonferroni corrected p value from ORA; Mean FC IG-mean fold change for upregulated imprinted genes; Mean FC Rest - mean fold change for all other upregulated genes; GSEA $p$ $\mathrm{p}$ value from Gene Set Enrichment Analysis for identity groups with 15+ IGs and Mean FC IG > Mean FC Rest; GSEA $q$ - Bonferroni corrected $p$ values from GSEA

\begin{tabular}{|c|c|c|c|c|c|c|c|c|}
\hline Identity & $\begin{array}{c}\text { Up Reg } \\
(14,027)\end{array}$ & $\begin{array}{l}\text { IG } \\
(93)\end{array}$ & ORA $p$ & ORA $q$ & $\begin{array}{c}\text { Mean FC } \\
\text { IG } \\
\end{array}$ & $\begin{array}{c}\text { Mean FC } \\
\text { Rest }\end{array}$ & $\begin{array}{c}\text { GSEA } \\
p \\
\end{array}$ & $\begin{array}{c}\text { GSEA } \\
q\end{array}$ \\
\hline Serotonergic Neurons & 1781 & 33 & $1.42 \mathrm{E}-08$ & $\underline{2.99 \mathrm{E}-07}$ & 4.78 & 2.36 & 0.0272 & 0.0544 \\
\hline Pericytes & 1409 & 22 & 0.000103 & $\underline{0.002161}$ & 8.57 & 8.04 & 0.2209 & 0.4418 \\
\hline Dopaminergic $1(T h)$ & 347 & 9 & 0.000484 & $\overline{0.010164}$ & 3.17 & 2.84 & - & - \\
\hline Dopaminergic 0 (Immature) & 219 & 7 & 0.000624 & $\underline{0.013114}$ & 4.03 & 2.91 & - & - \\
\hline Lateral Neuroblasts 2 & 2158 & 26 & 0.001353 & $\overline{0.028403}$ & 2.11 & 2.48 & - & - \\
\hline Oculomotor and trochlear nucleus & 1994 & 22 & 0.009922 & $\overline{0.208356}$ & 1.83 & 2.28 & - & - \\
\hline Mediolateral Neuroblasts 3 & 707 & 10 & 0.018500 & 0.388509 & 2.25 & 2.27 & - & - \\
\hline GABAergic neurons $1 \mathrm{~b}$ & 943 & 12 & 0.021628 & 0.454193 & 1.84 & 2.03 & - & - \\
\hline GABAergic neurons 1a & 743 & 10 & 0.025112 & 0.527346 & 2.05 & 2.12 & - & - \\
\hline Dopaminergic 2 (Aldhla1) & 464 & 7 & 0.034351 & 0.721369 & 3.22 & 3.43 & - & - \\
\hline Endothelial cell & 2555 & 24 & 0.042792 & 0.898639 & 7.38 & 8.31 & - & - \\
\hline Mediolateral Neuroblasts 1 & 302 & 5 & 0.050300 & 1 & 1.76 & 2.24 & - & - \\
\hline GABAergic neurons 2 & 5711 & 46 & 0.053803 & 1 & 1.89 & 1.95 & - & - \\
\hline
\end{tabular}




\begin{tabular}{|c|c|c|c|c|c|c|c|c|}
\hline Radial Glia-like Cells 3 & 1142 & 9 & 0.344985 & 1 & 3.43 & 5.45 & - & - \\
Red Nucleus & 1021 & 8 & 0.365408 & 1 & 2.21 & 2.01 & - \\
Mediolateral Neuroblasts 4 & 811 & 6 & 0.452000 & 1 & 1.54 & 2.42 & - \\
Microglia & 1293 & 7 & 0.765321 & 1 & 6.06 & 25.18 & - \\
Radial Glia-like Cells 1 & 1309 & 7 & 0.776475 & 1 & 3.08 & 2.79 & - \\
Ependymal & 1391 & 7 & 0.827678 & 1 & 3.49 & 13.28 & - \\
Neuronal Progenitor & 1775 & 9 & 0.847792 & 1 & 2.32 & 2.76 & - \\
Radial Glia-like Cells 2 & 1726 & 8 & 0.899405 & 1 & 2.89 & 3.41 & - \\
Lateral Neuroblasts 1 & 529 & 4 & - & - & 1.76 & 2.93 & - \\
Mediolateral Neuroblasts 5 & 125 & 4 & - & - & 1.86 & - & - \\
Neuroblast Dopaminergic & 196 & 3 & - & - & 3.55 & 2.14 & - & - \\
Medial Neuroblast & 313 & 2 & - & - & 1.48 & - & - & - \\
Mediolateral Neuroblasts 2 & 206 & 1 & - & - & 1.13 & - & - \\
\hline
\end{tabular}

As a final investigation, we used Tiklová et al.'s (2019) data in which purely dopamine neurons

450 (Pitx3+) of the ventral midbrain were sequenced. 3/7 dopaminergic subpopulations identified

451 in this study had significant over-representation of imprinted genes (Table 11). The Aldhlal+

452 neurons were localised to the SNc, Slc6a3+ neurons to the VTA and Vip+ neurons to the PAG.

453 The seven subpopulations were found to belong to two major subtypes of neurons by Tiklová

454 et al. (2019), Dat ${ }^{\text {High }}$ neurons with high expression of Th and Slc6a3 that made up $89 \%$ of Pitx3

455 positive neurons identified in the ventral midbrain, and Dat ${ }^{\text {Low }}$ neurons, the rarer Pitx3 positive

456 neurons lacking high expression of the typical dopamine markers (Th/Slc6a3). The 3 neuronal

457 subpopulations enriched here formed the entirety of the Dat ${ }^{\text {High }}$ subtype.

Table 11. Imprinted gene over-representation in Midbrain Dopamine Neuron Subtypes (Tiklová et al. 2019). Identity - Cell identities for the cells used in analysis; $U p$ Reg - number of upregulated genes with $q$ $\leq 0.05$ and positive Log2FC (total number of genes in the dataset in brackets); $I G$ - number of imprinted genes upregulated with $q \leq 0.05$ and positive Log2FC (total number of IGs in the dataset in brackets); ORA $p-p$ value from over representation analysis on groups with minimum 5\% of total IGs; ORA $q$-Bonferroni corrected $p$ value from ORA; Mean FC IG - mean fold change for upregulated imprinted genes; Mean FC Rest - mean fold change for all other upregulated genes.

\begin{tabular}{|c|c|c|c|c|c|c|}
\hline Identity & $\begin{array}{c}\text { Up Reg } \\
(\mathbf{2 4 , 0 7 9 )}\end{array}$ & $\begin{array}{c}\text { IG } \\
(\mathbf{1 0 4})\end{array}$ & ORA $\boldsymbol{p}$ & ORA $\boldsymbol{q}$ & Mean FC IG & Mean FC Rest \\
\hline Vip+ & 3534 & 29 & 0.000706 & $\mathbf{0 . 0 0 4 9 4 2}$ & 3.45 & 61.85 \\
Aldh1aI+ & 1215 & 14 & 0.001069 & $\mathbf{0 . 0 0 7 4 8 1}$ & 2.99 & 26.25 \\
Slc6a3+ & 1571 & 16 & 0.001696 & $\underline{\mathbf{0 . 0 1 1 8 6 9}}$ & 2.06 & 32.78 \\
Gad2 + Th & 3961 & 24 & 0.071815 & 0.502704 & 2.01 & 17.58 \\
Nxph4+Th & 4902 & 27 & 0.140455 & 0.983185 & 1.87 & 15.69 \\
Gad2+ & 1105 & 7 & 0.227457 & 1 & 1.46 & 101.14 \\
Nxph4+ & 2148 & 6 & 0.927658 & 1 & 1.65 & 76.49 \\
\hline
\end{tabular}

458 3cii) Imprinted genes are enriched in serotonergic neurons, specifically those projecting sub-

459 cortically

460 To examine enrichment of imprinted genes in serotonergic neurons further, analyses were

461 performed on data for the Raphe nuclei of the midbrain/hindbrain which are the key 
of the Dorsal Raphe Nucleus (DRN) revealed a clear enrichment of imprinted genes in the

the brainstem (Supplemental Table S14a). When compared to all other cell populations,

significant ORA was seen for Dopaminergic $(q=0.009)$, Serotonergic $(q=0.012)$ and

Peptidergic neurons $(q=0.0008)$, however, a significant GSEA was found for all five neuronal

populations (Appendix B7). When compared against each other (i.e. serotonergic upregulation

vs. the other neurons), only the serotonergic neurons of the DRN were found to have a

significant over- representation of imprinted genes (Table 12). GSEA's was also non-

significant but the mean fold change for imprinted genes was markedly higher in both

serotoninergic (52\% higher) and dopaminergic neurons (68\% higher).

Table 12. Imprinted gene over-representation in Dorsal Raphe Neuron types (Huang et al. 2019). Identity - Nervous System Regional identities for the cells used in analysis; Up Reg - number of upregulated genes with $q \leq 0.05$ and positive Log2FC (total number of genes in the dataset in brackets); $I G$-number of imprinted genes upregulated with $q \leq 0.05$ and positive Log2FC (total number of IGs in the dataset in brackets); ORA $p-p$ value from over representation analysis on groups with minimum 5\% of total IGs; ORA $q$-Bonferroni corrected $p$ value from ORA; Mean FC IG - mean fold change for upregulated imprinted genes; Mean FC Rest - mean fold change for all other upregulated genes; GSEA $p-p$ value from Gene Set Enrichment Analysis for identity groups with 15+ IGs and Mean FC IG > Mean FC Rest; GSEA $q$ - Bonferroni corrected $p$ values from GSEA.

\begin{tabular}{|c|c|c|c|c|c|c|c|c|}
\hline Identity & $\begin{array}{c}\text { Up Reg } \\
(\mathbf{1 4 , 3 9 7 )}\end{array}$ & $\begin{array}{c}\text { IG } \\
\mathbf{( 8 5})\end{array}$ & ORA $\boldsymbol{p}$ & ORA $\boldsymbol{q}$ & $\begin{array}{c}\text { Mean FC } \\
\text { IG }\end{array}$ & $\begin{array}{c}\text { Mean FC } \\
\text { Rest }\end{array}$ & $\begin{array}{c}\text { GSEA } \\
\boldsymbol{p}\end{array}$ & $\begin{array}{c}\text { GSEA } \\
\boldsymbol{q}\end{array}$ \\
\hline Serotonergic Neurons & 1275 & 18 & 0.000389 & $\underline{\mathbf{0 . 0 0 1 9 4 3}}$ & 4.03 & 2.66 & 0.1601 & 0.3202 \\
\hline Dopaminergic Neurons & 1520 & 15 & 0.031646 & 0.158232 & 4.93 & 2.93 & 0.1045 & 0.209 \\
\hline Glutamatergic Neurons & 3459 & 28 & 0.039052 & 0.195259 & 1.67 & 1.82 & - & - \\
\hline Peptidergic Neurons & 1298 & 11 & 0.141362 & 0.706809 & 1.83 & 6.42 & - & - \\
\hline GABAergic Neurons & 2796 & 19 & 0.285350 & 1 & 1.34 & 1.76 & - & - \\
\hline
\end{tabular}

473 The analysis was further broken down into neural subpopulations of all neuron types

474 (Supplemental Table S14b). 2/5 serotonin subpopulations had significant over-representation

475 of imprinted genes: Hcrtrl/Asb4 $-q=0.0014$ and Prkcq/Trh $-q=0.007$. These clusters were

476 identified by Huang et al. (2019) as the only clusters localised in the dorsal/lateral DRN and

477 the serotonin clusters enriched in Trh. Huang et al. (2019) hypothesised that these were the

478 serotonin neurons that project to hypothalamic nuclei, and motor nuclei in the brainstem (as

479 opposed to cortical/striatal projection).

Table 13. Imprinted gene over-representation in Raphe Serotonin neuron sub-types (Ren et al. 2019).

Identity - Nervous System Regional identities for the cells used in analysis; Up Reg - number of upregulated genes with $q \leq 0.05$ and positive Log2FC (total number of genes in the dataset in brackets); $I G$ - number of imprinted genes upregulated with $q \leq 0.05$ and positive Log2FC (total number of IGs in the dataset in brackets); ORA $p-p$ value from 
bioRxiv preprint doi: https://doi.org/10.1101/2020.07.27.222893; this version posted October 30, 2020. The copyright holder for this preprint (which was not certified by peer review) is the author/funder, who has granted bioRxiv a license to display the preprint in perpetuity. It is made available under aCC-BY-NC-ND 4.0 International license.

over representation analysis on groups with minimum 5\% of total IGs; ORA $q$ - Bonferroni corrected $p$ value from ORA; Mean FC IG - mean fold change for upregulated imprinted genes; Mean FC Rest - mean fold change for all other upregulated genes; GSEA $p-p$ value from Gene Set Enrichment Analysis for identity groups with 15+ IGs and Mean FC IG > Mean FC Rest; GSEA $q$ - Bonferroni corrected $p$ values from GSEA.

\begin{tabular}{|c|c|c|c|c|c|c|c|c|}
\hline Identity & $\begin{array}{r}\text { Up Reg } \\
(18,919)\end{array}$ & $\begin{array}{l}\text { IG } \\
(96)\end{array}$ & ORA $p$ & ORA $q$ & $\begin{array}{c}\text { Mean FC } \\
\text { IG }\end{array}$ & $\begin{array}{c}\text { Mean FC } \\
\text { Rest }\end{array}$ & GSEA $p$ & GSEA $q$ \\
\hline DR-6 & 1197 & 26 & $1.46 \mathrm{E}-10$ & $1.46 \mathrm{E}-09$ & 1.54 & 1.68 & - & - \\
\hline DR-1 & 1199 & 18 & $2.91 \mathrm{E}-05$ & 0.000291 & 2.15 & 2.07 & 0.0472 & 0.1416 \\
\hline MR-2 & 1925 & 21 & 0.000555 & $\overline{0.005554}$ & 1.62 & 1.6 & 0.4339 & 1 \\
\hline MR-1 & 2002 & 21 & 0.000927 & $\overline{0.00927}$ & 1.44 & 1.55 & - & - \\
\hline DR-5 & 1826 & 19 & 0.001862 & $\overline{0.018619}$ & 1.16 & 1.66 & - & - \\
\hline DR-2 & 3908 & 31 & 0.004993 & $\underline{0.049925}$ & 1.62 & 1.8 & - & - \\
\hline $\mathrm{cDR}$ & 1339 & 12 & 0.038173 & $\overline{0.381725}$ & 3.12 & 2.28 & - & - \\
\hline DR-3 & 2577 & 19 & 0.058054 & 0.580543 & 2.03 & 1.92 & 0.1602 & 0.4806 \\
\hline MR-3 & 1238 & 8 & 0.29177 & 1 & 1.18 & 2.03 & - & - \\
\hline MR-4 & 3475 & 15 & 0.793673 & 1 & 1.82 & 2.23 & - & - \\
\hline DR-4 & 1270 & 3 & - & - & 1.04 & 2.78 & - & - \\
\hline
\end{tabular}

480 Ren et al. (2019) sequenced serotonin neurons across the midbrain and pons identifying thirteen

481 subpopulations including six principle dorsal raphe population (DR), one caudal raphe

482 population (cDR) and four median raphe populations (MR). Imprinted gene over-

483 representation was found across numerous serotonergic subtypes including 4/6 DR populations

484 and 2/4 MR populations (Table 13). Since the majority of subtypes were considered over-

485 represented, the above analysis was run again with the $\log 2 \mathrm{FC} \geq 1$ criteria to find out if

486 imprinted genes were enriched in the more distinct markers (Supplemental Table S15). The

487 only significantly over-represented subpopulation in this more conservative analysis was DR-

$4881(q=0.005)$, a dorsal/lateral DR population with the largest enrichment of $\operatorname{Trh}$ (the marker for

489 serotonin neurons that project to subcortical areas - namely the hypothalamus and thalamus).

490 Figure 10 presents the Figure 10. Venn Diagrams of Upregulated Imprinted Genes in the overlapping upregulated Dopaminergic Neurons from Hook et al. 2019 and Huang et al. 2019. Right - Serotonin neurons and subtypes from Huang et al. 2019 and Ren et al. 2019 - Imprinted genes are listed which show significant upregulation $(q \leq 0.05$

492 imprinted genes from the and $\log 2 \mathrm{FC}>0$ ) in the subpopulation. Parental-bias is indicated by colour (MEG - red, PEG - blue).

493 convergently upregulated

494 neuron subtypes in the

495 monoaminergic analysis of

496 level 3c.

497

498 Discussion
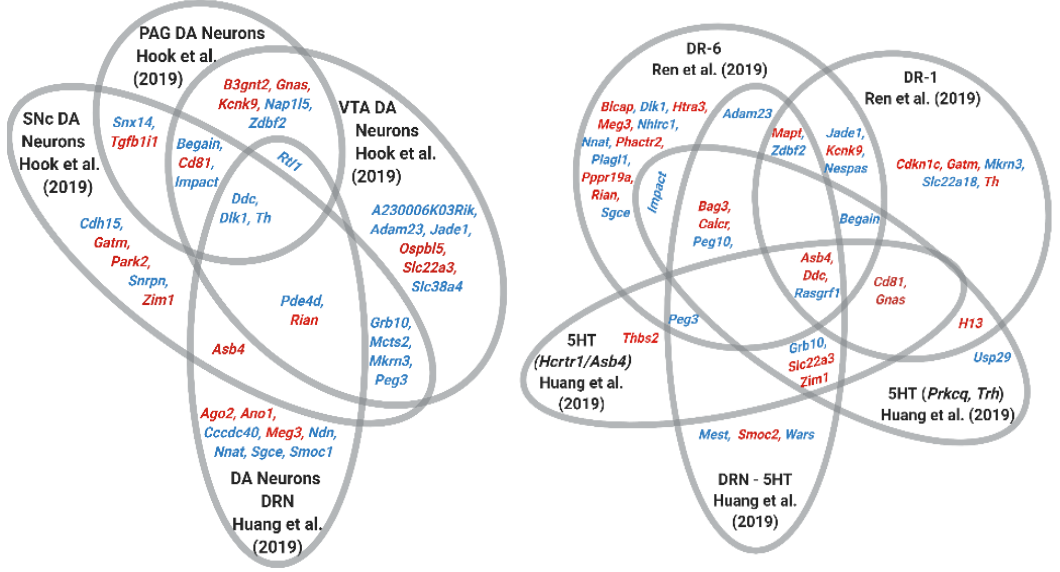
499 Here we apply an unbiased systems biology approach to examine the enrichment of imprinted

500 genes at the level of the brain in comparison to other adult tissues, refining this analysis to

501 specific brain regions and then to single cell populations. By analysing two independent adult

502 tissue datasets, we confirm a significant over-representation of imprinted genes in the brain.

503 Furthermore, imprinted genes were over-represented in neurons at every level tested with

504 marked enrichment in the neuroendocrine cells lineages. Within-brain analyses revealed that

505 the hypothalamus and the monoaminergic system of the midbrain/hindbrain were foci for

506 imprinted gene enrichment. While not all imprinted genes follow these patterns of expression,

507 this over-representation analysis highlights collective gene expression which is non-random in

508 nature. As such, these analyses identify 'expression hotspots', which in turn suggest 'functional

509 hotspots'. Specifically, our findings at the systems and cellular level highlight a major role for

510 imprinted genes in the neuronal regulation of feeding, parental behaviour and sleep.

511 Some of the earliest studies of genomic imprinting identified the brain as a key area for

512 imprinted gene expression (Allen et al. 1995; Keverne et al. 1996). However, it is estimated

513 that $\sim 80 \%$ of the genome is expressed in the brain and consequently, imprinted gene expression

514 in the brain might not be a purposeful phenomenon. Our current analysis revealed that

515 imprinted genes were statistically significantly over-represented in the brain as a whole. This

516 over-representation was mostly driven by paternally expressed genes (PEGs). Within specific

517 brain regions, imprinted genes were over-represented in the hypothalamus, ventral midbrain,

518 pons and medulla. This confirms some previous findings from studies of $\mathrm{Pg} / \mathrm{Gg}$ and $\mathrm{Ag}$ chimera

519 studies (Allen et al. 1995; Keverne et al. 1996) and summaries of imprinted gene expression

520 (Gregg et al. 2010). However, unlike these earlier studies, our analyses do not simply ask if

521 imprinted genes are expressed (at any level) or not, but robustly test whether this expression is

522 meaningful, and these genes are especially enriched in any given brain region. Additionally, in

523 the chimera studies, $\mathrm{Pg} / \mathrm{Gg}$ cells with two maternal genomes preferentially allocated to the 
524 developing adult cortex and hippocampus, and Ag cells with two paternal genomes preferentially allocated to the developing hypothalamus and midbrain. Our analysis does not reproduce this distinct pattern of maternally expressed gene (MEG) and PEG expression in the

527 brain, and indeed we find no specific enrichment of imprinted genes in cortex or hippocampus.

528 Although the pattern of regional enrichment seen with all imprinted genes is replicated when analysing PEGs alone, separate analysis of MEGs only shows over-representation in the pons and medulla. This difference between our analysis of enrichment and the $\mathrm{Pg} / \mathrm{Gg}$ and $\mathrm{Ag}$

531 chimeras studies indicate that the distribution of $\mathrm{Pg} / \mathrm{Gg}$ and $\mathrm{Ag}$ cells in the brain is not driven by, or indeed reflected by adult PEG and MEG expression, but instead is probably determined by developmental expression of key imprinted genes.

534 By taking advantage of scRNA-seq data we were able to examine imprinted gene enrichment in specific cell-types. At the whole brain level, mature neurons and, in particular, neural-lineage neuroendocrine cells had disproportionately higher numbers of imprinted genes expressed and high levels of imprinted gene expression. It is likely that this neural-lineage neuroendocrine population comprises members of the key hypothalamic populations in which imprinted genes

539 are enriched and, when treated as their own cluster, demonstrate strong imprinted gene enrichment compared to other cell lineages of the brain, even other mature neurons.

541 Within the hypothalamus, a selection of informative neuronal subpopulations were over-

542 represented. Strikingly, and suggestive of meaningful enrichment, we saw convergence across

543 our different levels of analysis with several key neuronal types identified in the whole

544 hypothalamus and/or hypothalamic-region-level analysis, already having been identified against the background of general imprinted gene expression in the whole-brain-level analysis.

546 These subpopulations are collectively associated with a few fundamental motivated

547 behaviours. Feeding behaviour is directly controlled by two Arcuate Nucleus populations: the 548 Agrp neurons, as feeding promotors, (which were enriched for imprinted genes at the whole 
brain level, in both whole hypothalamic level datasets and within the Arcuate nucleus) and the

Pomc neurons as feedings suppressants (enriched with the ARC dataset only) (Aponte et al.

2011). These neurons have already been associated with a few imprinted genes previously

population. Circadian process are controlled principally by the Suprachiasmatic Nucleus and

554 here we find strong imprinted gene enrichment in the circadian regulatory population -

Avp/Nms neurons (enriched at the whole brain level, the whole hypothalamic level and as the

only enriched neuronal type within the $\mathrm{SCN}$ ). This population is of interest given the growing

appreciation of the role imprinted genes play in circadian processes and the SCN suggested by

studies of individual imprinted genes (Tucci 2016). Pituitary endocrine regulation also emerged as an enriched function, considering the over-representation in the dopaminergic: prolactin and growth hormone release, respectively. Finally, neuronal control of parenting behaviour was also suggested from the enrichment we saw in the Gal/Esrl neuronal population of the Preoptic Area (enriched at whole brain, whole hypothalamic and at POA level). This neural population is known to be associated with feeding and, principally, parenting behaviour mediator of maternal-infant interaction priming the maternal brain during pregnancy for the nurturing of pups (Grattan et al. 2008).

569 In this analysis the hypothalamus was a clear hot spot for imprinted gene expression, in line with the prevailing view of imprinted gene and hypothalamic function (Ivanova and Kelsey emerged from our whole brain analysis including the monoaminergic system of the midbrain/hindbrain. Analysing the dorsal raphe nucleus and the ventral midbrain revealed the 
serotonergic neurons to be a foci of imprinted gene expression within this region; more specifically the serotonergic neurons that project to the subcortical regions of the brain known to be associated with feeding and other motivated behaviours (Donovan and Tecott 2013), mirroring the functional hotspots seen in the hypothalamus. In contrast to the specificity of the

578 imprinted gene enrichment in serotonergic neurons, the enrichment seen for adult midbrain 579 dopamine neurons was more generalised. Midbrain dopamine neurons were enriched in adult whole brain and developmental ventral midbrain analyses, and sub-type specific enrichment centred on the DAT ${ }^{\text {high }}$ lineage of midbrain DA neurons. These DAT ${ }^{\text {high }}$ neurons amount to the standard dopamine neurons (Th/Slc6a3 high) and are found throughout the VTA, SNc and PAG

583 (Tiklová et al. 2019) leading to little subdivision of the dopaminergic signal.

584 Analyses of these kind are always bound by the available data and therefore there are notable limitations and caveats to this study. The aim of this study was to generate information about 'hotspots' of imprinted gene expression. This approach, and the use over-representation analysis and GSEA, therefore do not provide an exhaustive list of sites of expression. For example, oxytocin neurons of the hypothalamus were not significantly enriched in any of the hypothalamic datasets despite a clear oxytocin neuron phenotype reported in a handful of imprinted gene models ( $\mathrm{Li}$ et al. 1999; Dombret et al. 2012). This may be an example of a functional effect occurring below the level of over-representation, or that imprinted genes act during development and are not functionally enriched in adult oxytocin neurons, or simply that compared to other hypothalamic neuronal populations, oxytocin neurons are not a 'hotspot' of

594 imprinted expression. Specific sequencing of oxytocinergic brain regions will be required to distinguish between these possibilities. A second caveat is that we did not assess parent-oforigin expression for the 119 imprinted genes we included in the analysis. Previous expression

597 profiling of imprinted genes have also not measured the POEs (Steinhoff et al. 2009; Gregg et al. 2010) but have restricted their gene selection to genes with reliable imprinting status. 
599 Consequently, we only included the canonical imprinted genes and genes with more than one

600 demonstration of a POE when looking for enrichment. Furthermore, for the vast majority of

601 these genes, a brain-based POE effect has also already been reported (Supplemental Table S1).

602 Although this does not replace validating the imprinting status of all 119 in the tissues and

603 subregions examined, it does provide justification for looking at imprinted gene over-

604 representation. To resolve this issue, scRNA-seq using hybrid tissues will be key; for example,

605 the recent work of Laukoter et al. (2020) with cortical cell types provides an example of the

606 allelic specific single-cell expression measurements necessary to confirm the enrichments

607 found in this study.

608 By exploiting scRNA-seq data we have asked whether imprinted genes as a group are 609 disproportionately represented in the brain, in specific brain regions, and in certain neuronal 610 cell-types. In the adult brain imprinted genes were over-represented in neurons, and particularly

611 the hypothalamic neuroendocrine populations and the monoaminergic hindbrain neurons, with

612 the serotonergic neurons demonstrating the clearest signal. Interestingly, PEGs appear to be

613 the major component of these enrichments, particularly the hypothalamic signal. By extension,

614 these data also identify behaviours that are foci for the action of imprinted genes. Although

615 there are high profile examples of individual imprinted genes that have a role in feeding

616 (Magel2) (Schaller et al. 2010), parental behaviour (Mest) (Lefebvre et al. 1998) and sleep

617 (Snord116) (Lassi et al. 2016), our analyses indicate that imprinted genes as a group are

618 strongly linked to these behaviours and also identify other individual genes that should be

619 explored in these domains. Conversely, there are high-profile examples of imprinted genes

620 involved in hippocampus related learning and memory (Ube3a) (Jiang et al. 1998), but we did

621 not find enrichment for cell types related to this brain function. The idea that imprinted genes

622 converge of specific physiological or behavioural processes is not unprecedented.

623 Specialisation of function is predicted when considering why genomic imprinting evolved at 
624 all (Moore and Haig 1991; Keverne et al. 1996b; Trivers and Burt 1999; Keverne 2014).

625 Moreover, there is increasing evidence that the imprinted genes themselves appear to be co-

626 expressed in an imprinted gene network (IGN) and have confirmed regulatory links between

627 each other (Varrault et al. 2006; Gabory et al. 2009; Al Adhami et al. 2015). The idea of the

628 IGN or, at the very least, heavily correlated and coordinated expression between imprinted 629 genes adds further support to the idea that imprinted genes work in concert to influence 630 processes, rather than in isolation, and that perturbating one may influence many others (Patten

631 et al. 2016). Our findings add substance to these general ideas and highlight the neuronal 632 regulation of feeding, parental behaviour and sleep as being key functional hotspots on which 633 imprinted genes converge which probably provides the best (but not perfect) basis for 634 discerning evolutionary drivers of genomic imprinting in the brain.

635

\section{Acknowledgments}

637 This work was supported by a Wellcome Trust PhD studentship (220090/Z/20/Z).

638

639 Competing interests

640 All authors declare no financial and non-financial competing interests

641

642

643

644

645

646

647 


\section{References}

Al Adhami H, Evano B, Le Digarcher A, Gueydan C, Dubois E, Parrinello H, Dantec C, Bouschet T, Varrault A, Journot L. 2015. A systems-level approach to parental genomic imprinting: the imprinted gene network includes extracellular matrix genes and regulates cell cycle exit and differentiation. Genome research 25: 353-367.

Allen ND, Logan K, Lally G, Drage DJ, Norris ML, Keverne EB. 1995. Distribution of parthenogenetic cells in the mouse brain and their influence on brain development and behavior. Proceedings of the National Academy of Sciences 92: 10782-10786.

Andergassen D, Dotter CP, Wenzel D, Sigl V, Bammer PC, Muckenhuber M, Mayer D, Kulinski TM, Theussl H-C, Penninger JM. 2017. Mapping the mouse Allelome reveals tissue-specific regulation of allelic expression. Elife 6: e25125.

Angulo M, Butler M, Cataletto M. 2015. Prader-Willi syndrome: a review of clinical, genetic, and endocrine findings. Journal of endocrinological investigation 38: 1249-1263.

Aponte Y, Atasoy D, Sternson SM. 2011. AGRP neurons are sufficient to orchestrate feeding behavior rapidly and without training. Nature neuroscience 14: 351.

Babak T, DeVeale B, Tsang EK, Zhou Y, Li X, Smith KS, Kukurba KR, Zhang R, Li JB, van der Kooy D. 2015. Genetic conflict reflected in tissue-specific maps of genomic imprinting in human and mouse. Nature genetics 47: 544-549.

Campbell JN, Macosko EZ, Fenselau H, Pers TH, Lyubetskaya A, Tenen D, Goldman M, Verstegen AM, Resch JM, McCarroll SA. 2017. A molecular census of arcuate hypothalamus and median eminence cell types. Nature neuroscience 20: 484-496.

Cassidy FC, Charalambous M. 2018. Genomic imprinting, growth and maternal-fetal interactions. Journal of Experimental Biology 221.

Cattanach BM, Kirk M. 1985. Differential activity of maternally and paternally derived chromosome regions in mice. Nature 315: 496-498.

Chen R, Wu X, Jiang L, Zhang Y. 2017. Single-cell RNA-seq reveals hypothalamic cell diversity. Cell reports $\mathbf{1 8 :}$ 3227-3241.

Davies JR, Humby T, Dwyer DM, Garfield AS, Furby H, Wilkinson LS, Wells T, Isles AR. 2015. Calorie seeking, but not hedonic response, contributes to hyperphagia in a mouse model for Prader-Willi syndrome. European Journal of Neuroscience 42: 2105-2113.

Dent CL, Humby T, Lewis K, Ward A, Fischer-Colbrie R, Wilkinson LS, Wilkins JF, Isles AR. 2018. Impulsive choice in mice lacking paternal expression of Grb10 suggests intragenomic conflict in behavior. Genetics 209: 233-239.

DeVeale B, Van Der Kooy D, Babak T. 2012. Critical evaluation of imprinted gene expression by RNA-Seq: a new perspective. PLoS Genet 8: e1002600.

Dombret C, Nguyen T, Schakman O, Michaud JL, Hardin-Pouzet H, Bertrand MJ, De Backer O. 2012. Loss of Maged1 results in obesity, deficits of social interactions, impaired sexual behavior and severe alteration of mature oxytocin production in the hypothalamus. Human molecular genetics 21: 47034717.

Donovan MH, Tecott LH. 2013. Serotonin and the regulation of mammalian energy balance. Frontiers in neuroscience 7: 36.

Ferguson-Smith AC. 2011. Genomic imprinting: the emergence of an epigenetic paradigm. Nature Reviews Genetics 12: 565-575.

Gabory A, Ripoche M-A, Le Digarcher A, Watrin F, Ziyyat A, Forné T, Jammes H, Ainscough JF, Surani MA, Journot L. 2009. H19 acts as a trans regulator of the imprinted gene network controlling growth in mice. Development 136: 3413-3421.

Garfield AS, Cowley M, Smith FM, Moorwood K, Stewart-Cox JE, Gilroy K, Baker S, Xia J, Dalley JW, Hurst LD. 2011. Distinct physiological and behavioural functions for parental alleles of imprinted Grb10. Nature 469: 534-538.

Grattan DR, Steyn FJ, Kokay IC, Anderson GM, Bunn SJ. 2008. Pregnancy-induced adaptation in the neuroendocrine control of prolactin secretion. Journal of neuroendocrinology 20: 497-507.

Gregg C, Zhang J, Weissbourd B, Luo S, Schroth GP, Haig D, Dulac C. 2010. High-resolution analysis of parentof-origin allelic expression in the mouse brain. science 329: 643-648.

Han X, Wang R, Zhou Y, Fei L, Sun H, Lai S, Saadatpour A, Zhou Z, Chen H, Ye F. 2018. Mapping the mouse cell atlas by microwell-seq. Cell 172: 1091-1107. e1017. 
bioRxiv preprint doi: https://doi.org/10.1101/2020.07.27.222893; this version posted October 30, 2020. The copyright holder for this preprint (which was not certified by peer review) is the author/funder, who has granted bioRxiv a license to display the preprint in perpetuity. It is made available under aCC-BY-NC-ND 4.0 International license.

Hook PW, McClymont SA, Cannon GH, Law WD, Morton AJ, Goff LA, McCallion AS. 2018. Single-cell RNA-seq of mouse dopaminergic neurons informs candidate gene selection for sporadic Parkinson disease. The American Journal of Human Genetics 102: 427-446.

Huang KW, Ochandarena NE, Philson AC, Hyun M, Birnbaum JE, Cicconet M, Sabatini BL. 2019. Molecular and anatomical organization of the dorsal raphe nucleus. Elife 8: e46464.

Ivanova E, Kelsey G. 2011. Imprinted genes and hypothalamic function. Journal of molecular endocrinology 47: R67-R74.

Jiang Y-h, Armstrong D, Albrecht U, Atkins CM, Noebels JL, Eichele G, Sweatt JD, Beaudet AL. 1998. Mutation of the Angelman ubiquitin ligase in mice causes increased cytoplasmic p53 and deficits of contextual learning and long-term potentiation. Neuron 21: 799-811.

Keverne E. 2014. Significance of epigenetics for understanding brain development, brain evolution and behaviour. Neuroscience 264: 207-217.

Keverne EB, Fundele R, Narasimha M, Barton SC, Surani MA. 1996a. Genomic imprinting and the differential roles of parental genomes in brain development. Developmental Brain Research 92: 91-100.

Keverne EB, Martel FL, Nevison CM. 1996b. Primate brain evolution: genetic and functional considerations. Proceedings of the Royal Society of London Series B: Biological Sciences 263: 689-696.

La Manno G, Gyllborg D, Codeluppi S, Nishimura K, Salto C, Zeisel A, Borm LE, Stott SR, Toledo EM, Villaescusa JC. 2016. Molecular diversity of midbrain development in mouse, human, and stem cells. Cell 167: 566-580. e519.

Lassi G, Ball ST, Maggi S, Colonna G, Nieus T, Cero C, Bartolomucci A, Peters J, Tucci V. 2012. Loss of Gnas imprinting differentially affects REM/NREM sleep and cognition in mice. PLoS Genet 8: e1002706.

Lassi G, Priano L, Maggi S, Garcia-Garcia C, Balzani E, El-Assawy N, Pagani M, Tinarelli F, Giardino D, Mauro A. 2016. Deletion of the Snord116/SNORD116 alters sleep in mice and patients with Prader-Willi syndrome. Sleep 39: 637-644.

Laukoter S, Pauler FM, Beattie R, Amberg N, Hansen AH, Streicher C, Penz T, Bock C, Hippenmeyer S. 2020. Cell-type specificity of genomic imprinting in cerebral cortex. Neuron 107: 1160-1179. e1169.

Lefebvre L, Viville S, Barton SC, Ishino F, Keverne EB, Surani MA. 1998. Abnormal maternal behaviour and growth retardation associated with loss of the imprinted gene Mest. Nature genetics 20: 163-169.

Lein ES, Hawrylycz MJ, Ao N, Ayres M, Bensinger A, Bernard A, Boe AF, Boguski MS, Brockway KS, Byrnes EJ. 2007. Genome-wide atlas of gene expression in the adult mouse brain. Nature 445: 168-176.

Li L-L, Keverne E, Aparicio S, Ishino F, Barton S, Surani M. 1999. Regulation of maternal behavior and offspring growth by paternally expressed Peg3. Science 284: 330-334.

McNamara GI, John RM, Isles AR. 2018. Territorial behavior and social stability in the mouse require correct expression of imprinted Cdkn1c. Frontiers in behavioral neuroscience 12: 28.

Mickelsen LE, Bolisetty M, Chimileski BR, Fujita A, Beltrami EJ, Costanzo JT, Naparstek JR, Robson P, Jackson AC. 2019. Single-cell transcriptomic analysis of the lateral hypothalamic area reveals molecularly distinct populations of inhibitory and excitatory neurons. Nature neuroscience 22: 642-656.

Moffitt JR, Bambah-Mukku D, Eichhorn SW, Vaughn E, Shekhar K, Perez JD, Rubinstein ND, Hao J, Regev A, Dulac C. 2018. Molecular, spatial, and functional single-cell profiling of the hypothalamic preoptic region. Science 362.

Moore T, Haig D. 1991. Genomic imprinting in mammalian development: a parental tug-of-war. Trends in genetics 7: 45-49.

Negi SK, Guda C. 2017. Global gene expression profiling of healthy human brain and its application in studying neurological disorders. Scientific reports 7: 1-12.

Nicholls RD, Knoll JH, Butler MG, Karam S, Lalande M. 1989. Genetic imprinting suggested by maternal heterodisomy in non-deletion Prader-Willi syndrome. Nature 342: 281-285.

Orr HA. 1995. Somatic mutation favors the evolution of diploidy. Genetics 139: 1441-1447.

Patten MM, Cowley M, Oakey RJ, Feil R. 2016. Regulatory links between imprinted genes: evolutionary predictions and consequences. Proceedings of the Royal Society B: Biological Sciences 283: 20152760.

Perez JD, Rubinstein ND, Dulac C. 2016. New Perspectives on Genomic Imprinting, an Essential and Multifaceted Mode of Epigenetic Control in the Developing and Adult Brain. Annual Review of Neuroscience 39: 347-384.

Perez JD, Rubinstein ND, Fernandez DE, Santoro SW, Needleman LA, Ho-Shing O, Choi JJ, Zirlinger M, Chen S-K, Liu JS. 2015. Quantitative and functional interrogation of parent-of-origin allelic expression biases in the brain. Elife 4: e07860.

Peters J. 2014. The role of genomic imprinting in biology and disease: an expanding view. Nature Reviews Genetics 15: 517-530. 
Pulix M, Plagge A. 2020. Imprinted Genes and Hypothalamic Function. In Developmental Neuroendocrinology, pp. 265-294. Springer.

Qualls-Creekmore E, Yu S, Francois M, Hoang J, Huesing C, Bruce-Keller A, Burk D, Berthoud H-R, Morrison CD, Münzberg H. 2017. Galanin-expressing GABA neurons in the lateral hypothalamus modulate food reward and noncompulsive locomotion. Journal of Neuroscience 37: 6053-6065.

Rau AR, Hentges ST. 2017. The relevance of AgRP neuron-derived GABA inputs to POMC neurons differs for spontaneous and evoked release. Journal of Neuroscience 37: 7362-7372.

Relkovic D, Doe CM, Humby T, Johnstone KA, Resnick JL, Holland AJ, Hagan JJ, Wilkinson LS, Isles AR. 2010. Behavioural and cognitive abnormalities in an imprinting centre deletion mouse model for PraderWilli syndrome. European journal of neuroscience 31: 156-164.

Ren J, Isakova A, Friedmann D, Zeng J, Grutzner SM, Pun A, Zhao GQ, Kolluru SS, Wang R, Lin R. 2019. Singlecell transcriptomes and whole-brain projections of serotonin neurons in the mouse dorsal and median raphe nuclei. Elife 8: e49424.

Romanov RA, Zeisel A, Bakker J, Girach F, Hellysaz A, Tomer R, Alpár A, Mulder J, Clotman F, Keimpema E. 2017. Molecular interrogation of hypothalamic organization reveals distinct dopamine neuronal subtypes. Nature neuroscience 20: 176-188.

Schaller F, Watrin F, Sturny R, Massacrier A, Szepetowski P, Muscatelli F. 2010. A single postnatal injection of oxytocin rescues the lethal feeding behaviour in mouse newborns deficient for the imprinted Magel2 gene. Human Molecular Genetics 19: 4895-4905.

Schaum N, Karkanias J, Neff NF, May AP, Quake SR, Wyss-Coray T, Darmanis S, Batson J, Botvinnik O, Chen MB. 2018. Single-cell transcriptomics of 20 mouse organs creates a Tabula Muris: The Tabula Muris Consortium. Nature 562: 367.

Steinhoff C, Paulsen M, Kielbasa S, Walter J, Vingron M. 2009. Expression profile and transcription factor binding site exploration of imprinted genes in human and mouse. BMC Genomics 10: 144.

Subramanian A, Tamayo P, Mootha VK, Mukherjee S, Ebert BL, Gillette MA, Paulovich A, Pomeroy SL, Golub TR, Lander ES. 2005. Gene set enrichment analysis: a knowledge-based approach for interpreting genome-wide expression profiles. Proceedings of the National Academy of Sciences 102: 1554515550.

Team R. 2015. RStudio: integrated development for R. RStudio, Inc, Boston, MA URL http://wwwrstudio.com 42: 14.

Team RC. 2013. R: A language and environment for statistical computing. Vienna, Austria.

Tiklová K, Björklund ÅK, Lahti L, Fiorenzano A, Nolbrant S, Gillberg L, Volakakis N, Yokota C, Hilscher MM, Hauling T. 2019. Single-cell RNA sequencing reveals midbrain dopamine neuron diversity emerging during mouse brain development. Nature communications 10: 1-12.

Trivers R, Burt A. 1999. Kinship and genomic imprinting. In Genomic imprinting, pp. 1-21. Springer.

Tucci V. 2016. Genomic imprinting: a new epigenetic perspective of sleep regulation. PLoS genetics 12: e1006004.

Tucci V, Isles AR, Kelsey G, Ferguson-Smith AC, Bartolomei MS, Benvenisty N, Bourc'his D, Charalambous M, Dulac C, Feil R. 2019. Genomic imprinting and physiological processes in mammals. Cell 176: 952-965.

Varrault A, Gueydan C, Delalbre A, Bellmann A, Houssami S, Aknin C, Severac D, Chotard L, Kahli M, Le Digarcher A. 2006. Zac1 regulates an imprinted gene network critically involved in the control of embryonic growth. Developmental cell 11: 711-722.

Wen S, Ma D, Zhao M, Xie L, Wu Q, Gou L, Zhu C, Fan Y, Wang H, Yan J. 2020. Spatiotemporal single-cell analysis of gene expression in the mouse suprachiasmatic nucleus. Nature neuroscience 23: 456.

Ximerakis M, Lipnick SL, Innes BT, Simmons SK, Adiconis X, Dionne D, Mayweather BA, Nguyen L, Niziolek Z, Ozek C. 2019. Single-cell transcriptomic profiling of the aging mouse brain. Nature neuroscience $\mathbf{2 2}$ : 1696-1708.

Zeisel A, Hochgerner H, Lönnerberg P, Johnsson A, Memic F, Van Der Zwan J, Häring M, Braun E, Borm LE, La Manno G. 2018. Molecular architecture of the mouse nervous system. Cell 174: 999-1014. e1022. 
bioRxiv preprint doi: https://doi.org/10.1101/2020.07.27.222893; this version posted October 30, 2020. The copyright holder for this preprint (which was not certified by peer review) is the author/funder, who has granted bioRxiv a license to display the preprint in perpetuity. It is made available under aCC-BY-NC-ND 4.0 International license.

\section{Appendix A - Comparison of Upregulated Genes for GABA5 in Romanov et al. (2017) and GABA17}

814 in Chen et al. (2017). 21 genes were upregulated in both subgroups which is over 50\% of the upregulated genes found in

815 GABA5 including the top 5 marker genes. Position of genes organised by $p$ value is included for both subtypes alongside the

$816 p$ values, Bonferroni corrected $q$ values, and the fold change $(\mathrm{FC})$ values for expression in this neuronal subpopulation vs.

817 background. Prlr is a notable absentee; it is an upregulated gene in GABA17 but was not significant among the more restrictive

818 markers of GABA 5 despite having a fold change of 1.86 vs. background.

\begin{tabular}{|c|c|c|c|c|c|c|c|c|}
\hline Gene & $\begin{array}{l}\text { Position in } \\
\text { GABA5 } \\
\text { sorted by } p \\
\text { (41 upreg } \\
\text { genes) }\end{array}$ & $\begin{array}{c}\text { GABA5 } \\
p\end{array}$ & $\begin{array}{c}\text { GABA5 } \\
q\end{array}$ & $\begin{array}{c}\text { GABA5 } \\
\text { FC }\end{array}$ & $\begin{array}{c}\text { Position in } \\
\text { GABA17 } \\
\text { sorted by } p \\
\text { (823 upreg } \\
\text { genes) }\end{array}$ & GABA17 $p$ & GABA17 $q$ & $\begin{array}{c}\text { GABA17 } \\
\text { FC }\end{array}$ \\
\hline Calcr & 1 & $2.09 \mathrm{E}-38$ & $1.30 \mathrm{E}-36$ & 8.13 & 41 & $4.12 \mathrm{E}-13$ & 4.67E-12 & 4.96 \\
\hline Lhx 1 & 2 & $1.82 \mathrm{E}-10$ & $1.13 \mathrm{E}-08$ & 9.56 & 29 & $1.35 \mathrm{E}-16$ & $1.53 \mathrm{E}-15$ & 4.74 \\
\hline Slc6a3 & 3 & $6.44 \mathrm{E}-09$ & $1.33 \mathrm{E}-07$ & 15.71 & 1 & $2.20 \mathrm{E}-111$ & 7.47E-110 & 69.29 \\
\hline Asb4 & 4 & $6.76 \mathrm{E}-08$ & $4.19 \mathrm{E}-06$ & 2.82 & 443 & 0.000408 & 0.002311 & 1.99 \\
\hline 1500016L03Rik & 5 & $1.13 \mathrm{E}-07$ & $3.50 \mathrm{E}-06$ & 4.74 & 23 & $1.25 \mathrm{E}-19$ & $1.42 \mathrm{E}-18$ & 4.61 \\
\hline Npbwr1 & 7 & 8.22E-06 & 0.000510 & 9.02 & 817 & 0.008319 & 0.047138 & 3.55 \\
\hline Diap3 & 9 & 4.79E-05 & 0.002967 & 7.51 & 12 & $1.73 \mathrm{E}-27$ & $5.87 \mathrm{E}-26$ & 9.97 \\
\hline Gpr83 & 11 & 0.000118 & 0.003456 & 4.27 & 14 & $3.49 \mathrm{E}-25$ & $1.19 \mathrm{E}-23$ & 6.27 \\
\hline Slc18a2 & 13 & 0.000158 & 0.001961 & 3.24 & 3 & $9.52 \mathrm{E}-44$ & $1.62 \mathrm{E}-42$ & 9.43 \\
\hline Peg10 & 16 & 0.000240 & 0.004955 & 2.25 & 40 & $9.95 \mathrm{E}-14$ & $3.38 \mathrm{E}-12$ & 2.46 \\
\hline Dlk1 & 20 & 0.000324 & 0.009853 & 1.89 & 123 & $1.24 \mathrm{E}-07$ & $1.05 \mathrm{E}-06$ & 1.93 \\
\hline Fam159b & 21 & 0.000371 & 0.007659 & 4.98 & 71 & $5.46 \mathrm{E}-10$ & $6.19 \mathrm{E}-09$ & 4.19 \\
\hline Rab3b & 25 & 0.000462 & 0.009550 & 1.85 & 30 & $1.39 \mathrm{E}-16$ & 4.72E-15 & 1.96 \\
\hline Six6 & 26 & 0.000526 & 0.008157 & 4.35 & 11 & $1.01 \mathrm{E}-27$ & $3.45 \mathrm{E}-26$ & 6.41 \\
\hline AA388235 & 31 & 0.000863 & 0.036304 & 3.79 & 82 & 2.36E-09 & 8.01E-08 & 10.61 \\
\hline Hnrnpul1 & 34 & 0.001399 & 0.043371 & 3.87 & 600 & 0.001031 & 0.035041 & 2.20 \\
\hline Arhgap36 & 37 & 0.001821 & 0.028222 & 2.19 & 46 & $2.61 \mathrm{E}-12$ & $4.44 \mathrm{E}-11$ & 3.50 \\
\hline Th & 38 & 0.002050 & 0.014126 & 2.24 & 8 & $1.45 \mathrm{E}-35$ & $2.46 \mathrm{E}-34$ & 8.29 \\
\hline Dlx2 & 39 & 0.002801 & 0.034730 & 4.09 & 138 & 4.42E-07 & 3.01E-06 & 3.23 \\
\hline Dlx6 & 40 & 0.003047 & 0.047231 & 9.07 & 192 & 5.23E-06 & $5.93 \mathrm{E}-05$ & 3.53 \\
\hline Dlx1 & 41 & 0.006400 & 0.036074 & 2.07 & 34 & $1.23 \mathrm{E}-15$ & $2.08 \mathrm{E}-14$ & 3.60 \\
\hline
\end{tabular}

819

820

821 
bioRxiv preprint doi: https://doi.org/10.1101/2020.07.27.222893; this version posted October 30, 2020. The copyright holder for this preprint (which was not certified by peer review) is the author/funder, who has granted bioRxiv a license to display the preprint in perpetuity. It is made available under aCC-BY-NC-ND 4.0 International license.

825 Appendix B - Significant GSEA not included in the main text. In the analysis, genes are sorted by strength

826 by which they mark this neuronal cluster (sorted by fold change values) indicated by the bar (bottom). The genes are arrayed

827 left (strongest marker) to right and blue lines mark where imprinted genes fall on this array. The vertical axis indicates an

828 accumulating weight, progressing from left to right and increasing or decreasing depending on whether the next gene is an

829 imprinted gene or not. The $p$-value represents the probability of observing the maximum value of the score (red dashed line)

830 if the imprinted genes are distributed randomly along the horizontal axis. For some analyses, Dot plots of Upregulated

831 imprinted genes in that cell type, separated by MEGs and PEGs, were plotted across all cell types in that analysis. Size of

832 points represented absolute mean expression; colour represented the size of the Log2FC value for neuroendocrine

833 cells vs. all other cells.

834 Appendix B1 - Pancreas GSEA of PEGs vin Mouse Cell Atlas (Han et al. 2018)

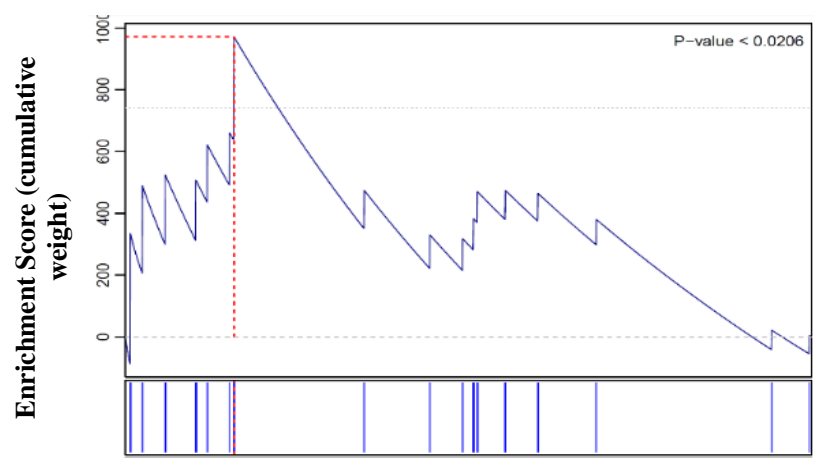

Sorted Genes (by descending Log2FC)

835 Appendix B2 - Neuroendocrine Cell GSEA for PEGs in Whole Brain Analysis (Ximerakis et a., 2019)

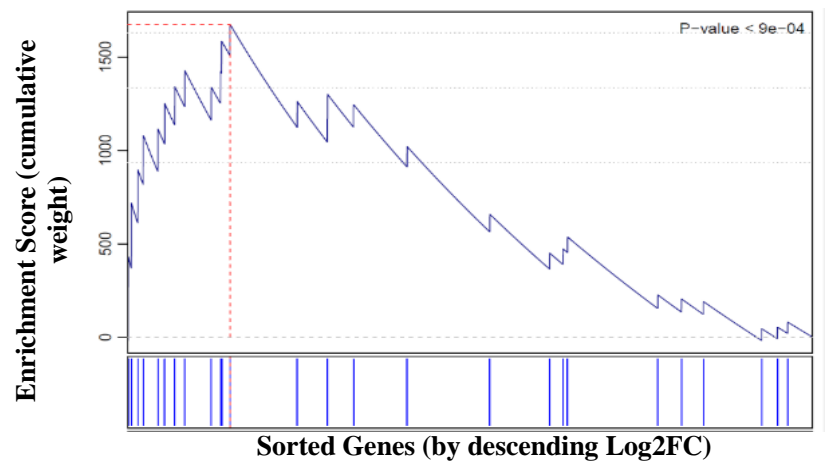

836 Appendix B3 - Pons GSEA for MEGS in Mouse Brain Atlas Analysis (Zeisel et al. 2018), $q=0.028$

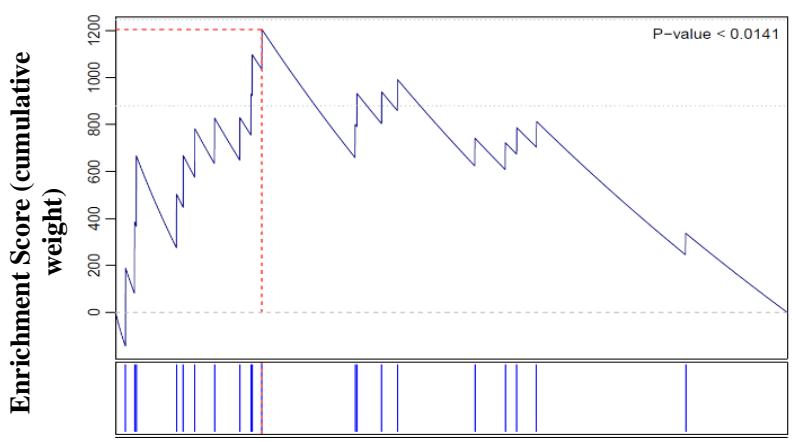

Sorted Genes (by descending Log2FC) 
bioRxiv preprint doi: https://doi.org/10.1101/2020.07.27.222893; this version posted October 30, 2020. The copyright holder for this preprint (which was not certified by peer review) is the author/funder, who has granted bioRxiv a license to display the preprint in perpetuity. It is made available under aCC-BY-NC-ND 4.0 International license.

837 Appendix B4 - Hindbrain Serotonin neurons (left to right, top to bottom - HBSER2, HBSER4, HBSER5)

838 GSEA in Mouse Brain Atlas (Zeisel et al. 2020). Left - GSEA plots for the three enriched serotonin populations after 839 Bonferroni Correction. Right - Dot Plot of upregulated imprinted genes across the 3 enriched serotonin neuron populations 840 plotted across all over-represented neuron subpopulations.

841

842

$\underline{\operatorname{HBSER} 2(q=0.044)}$

843

844

845

846

847

848

849

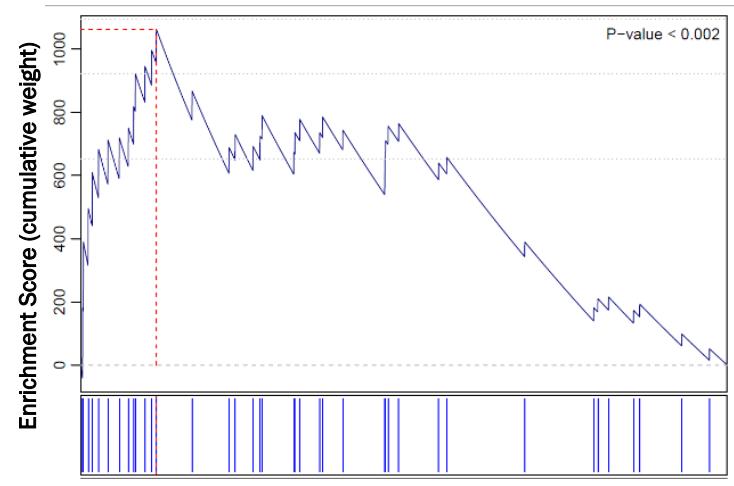

850

Sorted Genes (by descending Log2FC)

851

852

853

854

855

856

857

858

$\underline{\operatorname{HBSER} 4(q=0.011)}$

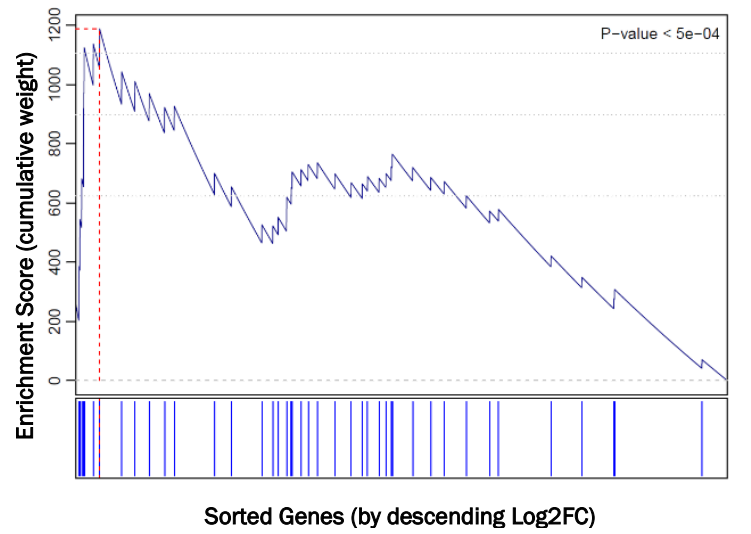

859

860

861

862

863

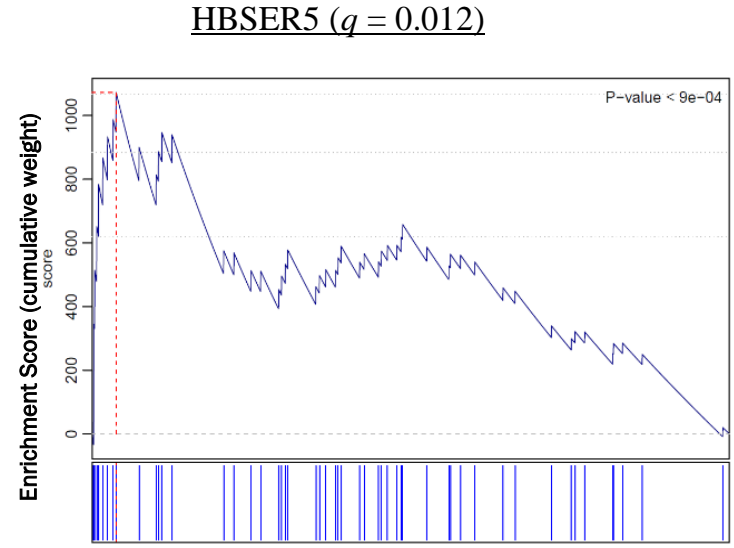

Sorted Genes (by descending Log2FC)

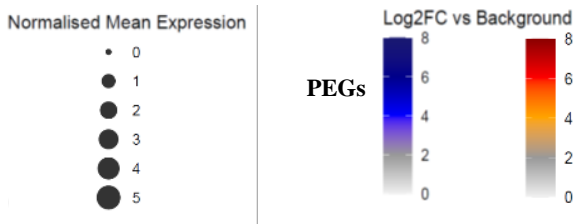

MEGs

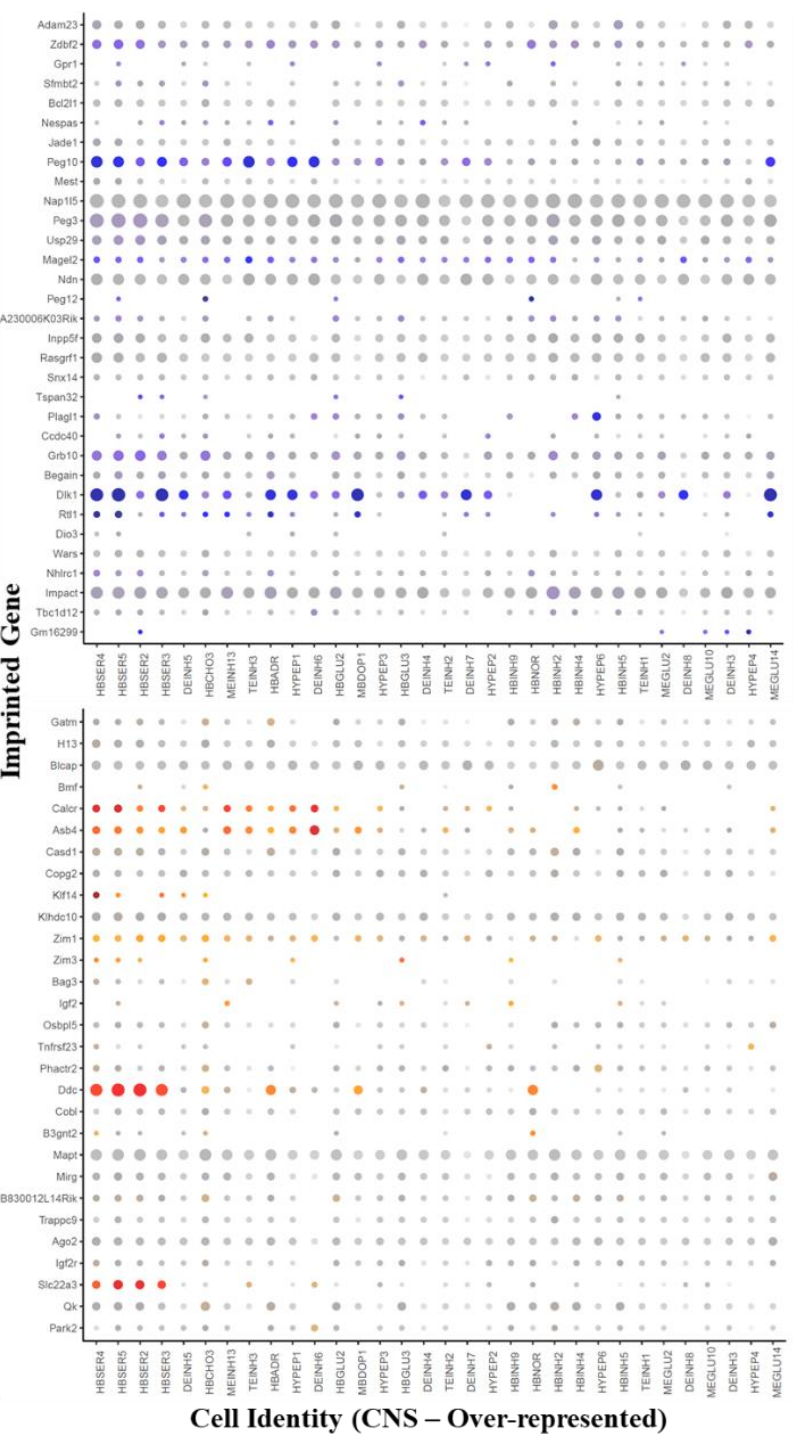


bioRxiv preprint doi: https://doi.org/10.1101/2020.07.27.222893; this version posted October 30, 2020. The copyright holder for this preprint (which was not certified by peer review) is the author/funder, who has granted bioRxiv a license to display the preprint in perpetuity. It is made available under aCC-BY-NC-ND 4.0 International license.

Appendix B5 - Glut_9 (Synpr/Gad1) neurons in LHA (Mickelsen et al. 2019), $q=0.0198$.

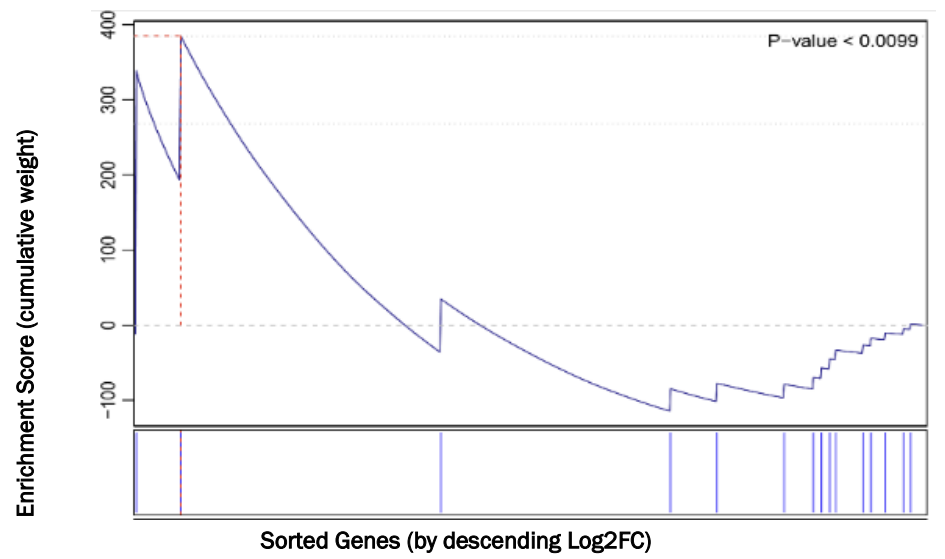

Appendix B6 - Avp/Nms neurons in SCN (Wen et al. 2020). Top - GSEA plot for AVP/NMS neurons in SCN, Bottom - Dot Plot of expression of upregulated imprinted genes in Avp/Nms Neurons plotted across all SCN neuron types.
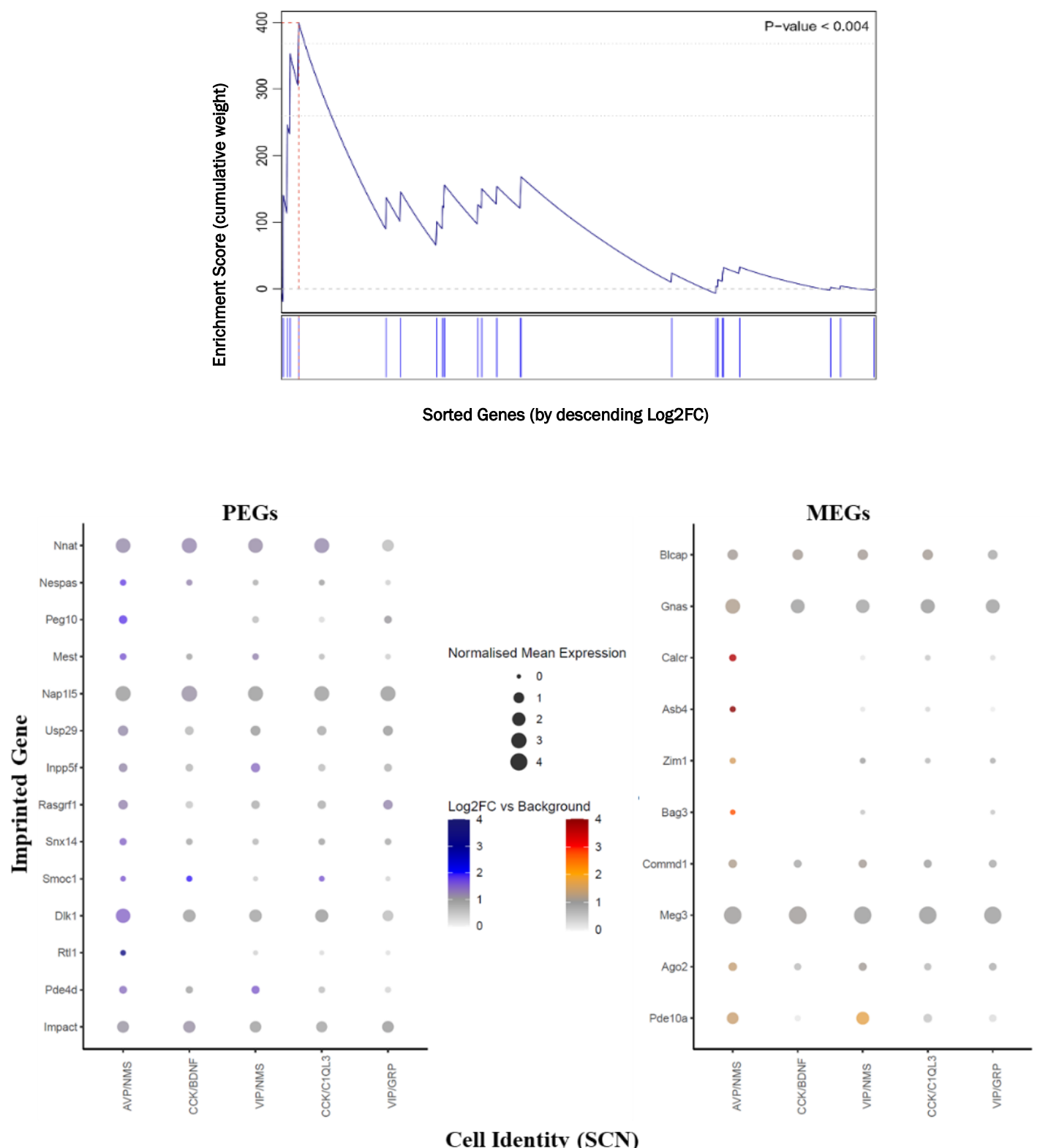
bioRxiv preprint doi: https://doi.org/10.1101/2020.07.27.222893; this version posted October 30, 2020. The copyright holder for this preprint (which was not certified by peer review) is the author/funder, who has granted bioRxiv a license to display the preprint in perpetuity. It is made available under aCC-BY-NC-ND 4.0 International license.

868 Appendix B7 - Dorsal Raphe Nucleus (Huang et al. 2019) (left, top to bottom - Serotonin neurons, Dopamine 869 neurons, GABA neurons, Glutamatergic neurons, Peptidergic neurons). Right - Dot plots of the expression of all 870 imprinted genes, upregulated across the 5 neuron types, plotted across all cells in the DRN.

871 Serotonergic Neurons $(q=0.0005)$
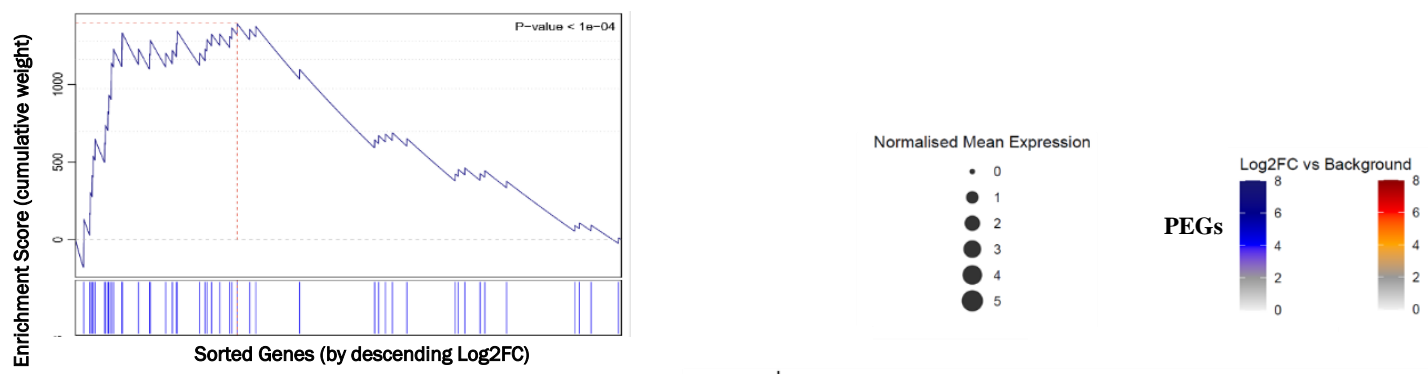

MEGs

872 Dopaminergic Neurons $(q=0.0005)$

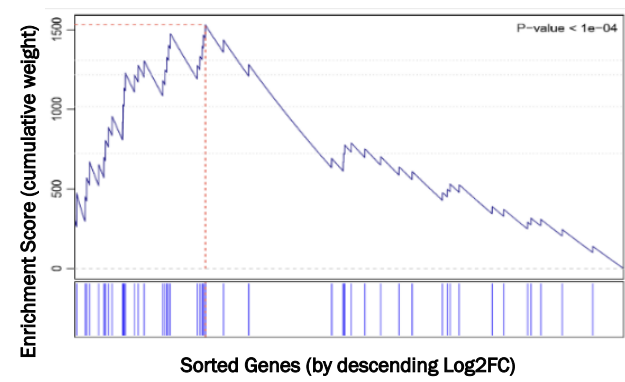

$873 \underline{\text { GABAergic Neurons }(q=0.003)}$
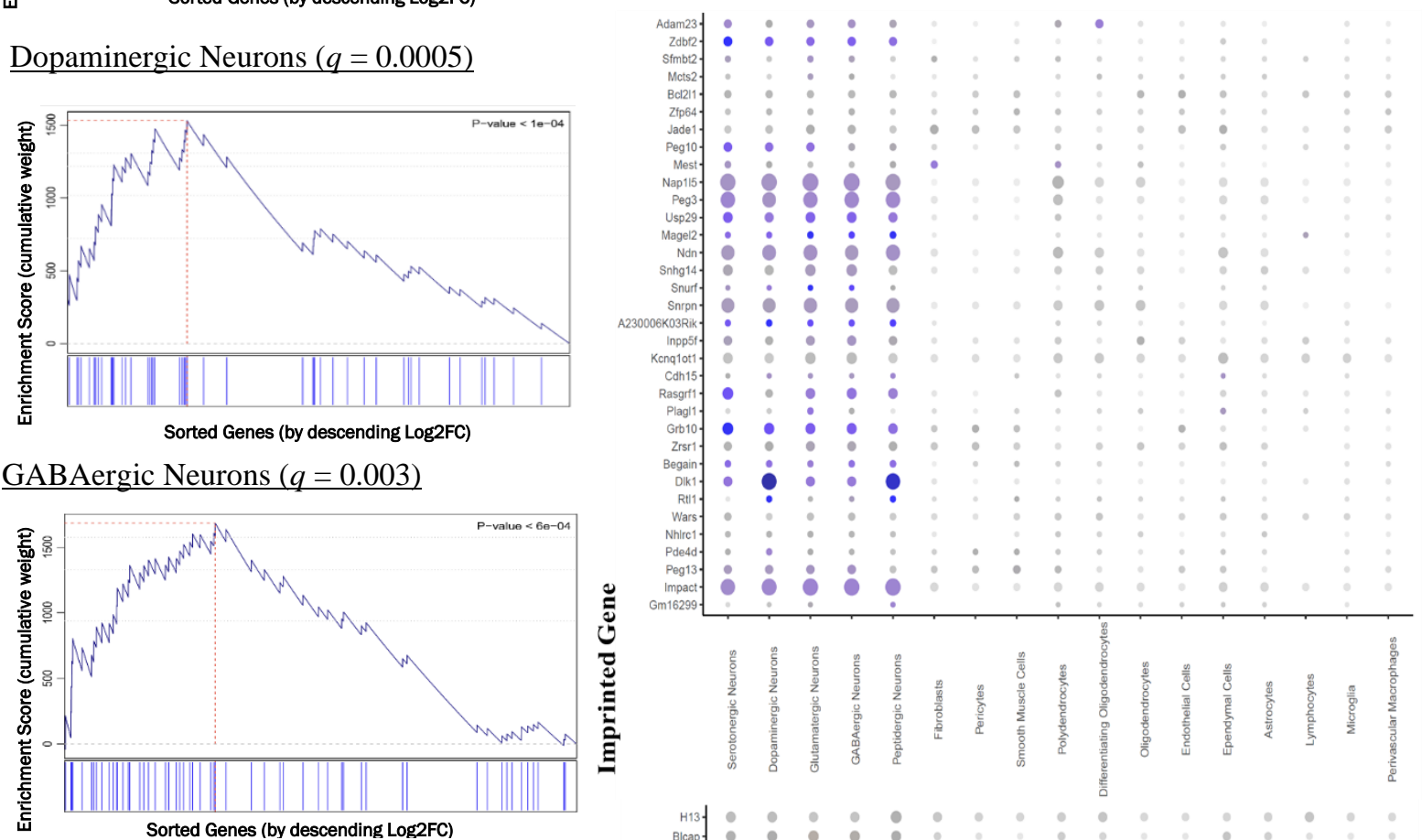

874 Glutamatergic Neurons $(q=0.0035)$

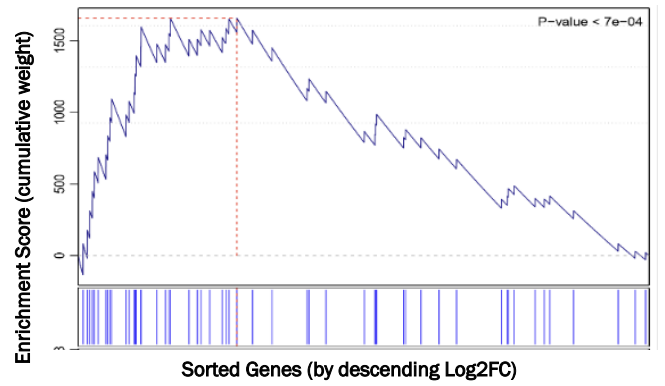

875 Peptidergic Neurons $(q=0.034)$
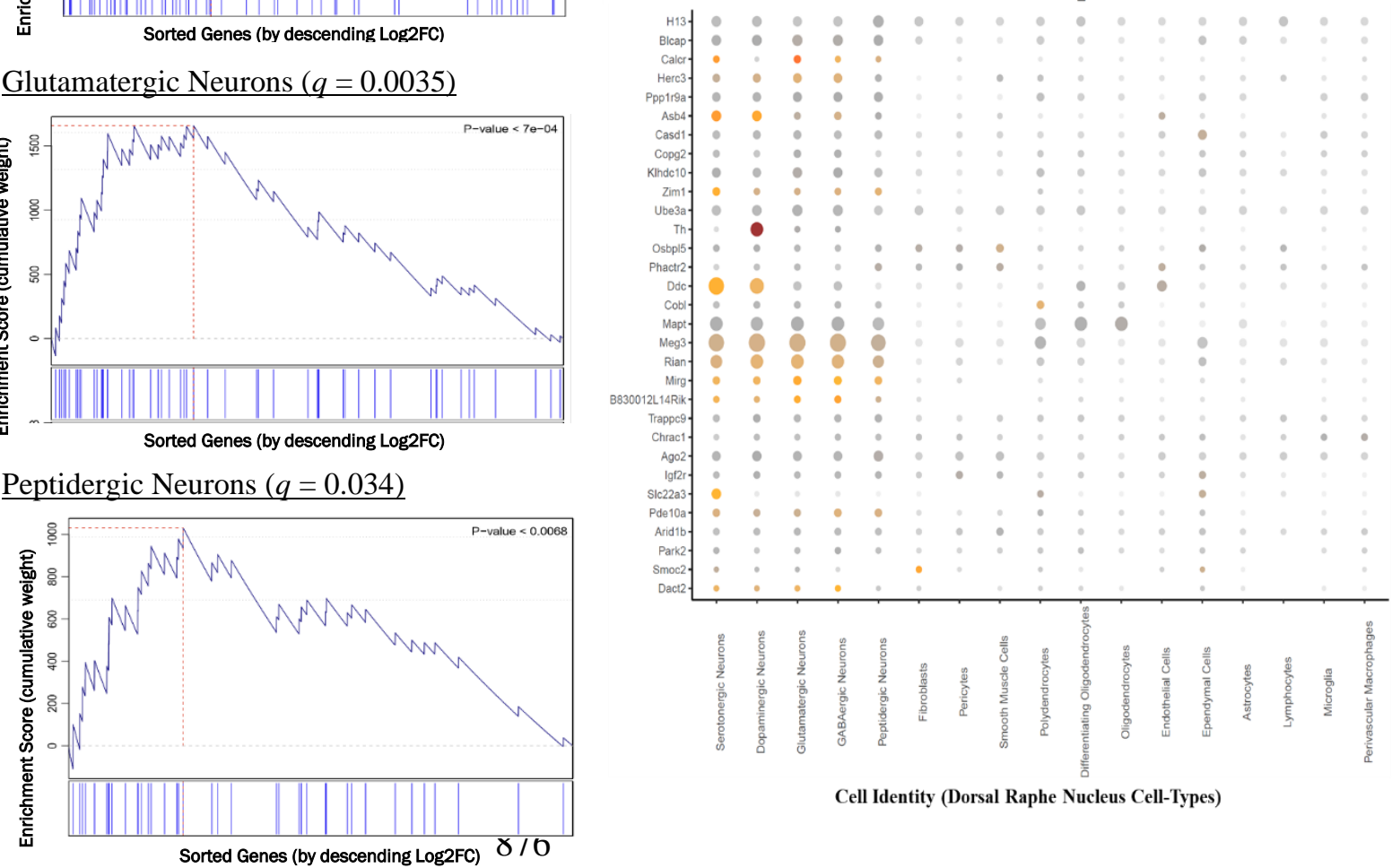

Cell Identity (Dorsal Raphe Nucleus Cell-Types) 